\title{
Can taxes tame the banks? Evidence from the European bank levies
}

\author{
Michael Devereux \\ Niels Johannesen \\ Oxford University Centre for Business Taxation \\ University of Copenhagen \\ John Vella \\ Oxford University Centre for Business Taxation
}

March 14, 2019

\begin{abstract}
Following the 2007-2008 financial crisis, a large number of countries introduced levies on bank borrowing intended to reduce risk in the financial sector. This paper studies the behavioral responses to bank levies and finds that banks exposed to levies increased their reliance on equity funding, but at the same time increased the risk of their assets; banks shifted risk from the liability side of their balance sheets to the asset side, which mitigated the impact of government intervention. Our analysis also shows that any reduction in total risk was concentrated among banks that pose no or little threat to financial stability.
\end{abstract}




\section{Introduction}

The financial crisis in 2007-2008 was a painful reminder that excessive risk-taking by banks can impose very significant costs on governments (Laeven and Valencia, 2013), non-financial firms (Chodorow-Reich, 2014) and households (Jensen and Johannesen, 2017) and thus revived old debates about government intervention in the financial sector. Many scholars have argued in favor of tightening capital requirements (e.g. Admati et al., 2010; Hart and Zingales, 2011) while others have proposed to address excessive bank risk with tax instruments (IMF, 2010; Acharaya et al., 2016) and theoretically explored the interaction between taxation and regulation in financial markets (Keen, 2011).

Since the crisis, a number of European countries have indeed adopted a new type of taxes on banks. The taxes, known as bank levies, typically fall directly on banks' borrowing and have a clear Pigouvian rationale: given that the social cost of bank distress exceeds the private cost, there is scope for a corrective tax on the types of bank funding that increase the risk of distress. Concretely, a typical bank levy adds around 0.05\% to the cost of borrowing in money markets where interest rates have been less than $2 \%$ throughout the post-crisis period. By raising the cost of borrowing, the levies are designed to make banks rely more on equity funding and thus increase stability in the financial sector. Besides the corrective effect on bank behavior, the introduction of bank levies was also motivated by the desire to extract more revenue from the financial sector.

Theoretically, levies on bank borrowing should clearly induce banks to rely more on equity funding: starting from an optimal capital structure where the marginal costs and benefits of all sources of funding are equalized, a higher cost of debt should cause substitution toward equity. However, the effect on total risk is theoretically ambiguous because banks may also adjust their portfolio choices. In some classes of models, funding risk and portfolio risk are substitutes: when policy interventions induce banks to reduce funding risk, they optimally take on more portfolio risk, which limits the effect on total risk (e.g. Koehn and Santomero, 1980; Devereux, 2014). In other classes of models, funding risk and portfolio risk are complements: banks with more equity also hold safer assets because moral hazard problems caused by limited liability are attenuated (e.g. Allen, Carletti and Marquez, 2011).

This paper studies empirically how a bank levy shapes banks' funding and portfolio 
choices and how it affects their total risk. We draw on detailed information from the financial reports of more than 2,700 European banks as well as market information for listed banks and exploit that the adoption of bank levies in Europe constitutes a rich natural experiment with several types of variation. Specifically, 14 countries in the European Union adopted levies in the aftermath of the financial crisis, with pronounced differences in the base, the rate structure and the timing of the implementation, while the remaining 13 countries did not.

Our analysis exploits this variation in banks' exposure to levies in a panel model that controls for standard bank-level and country-level determinants of capital structure. Since we ultimately identify the effect of the levies from comparisons across banks in different countries, we are careful to control for unobserved factors in a number of ways. First, our preferred specification includes bank fixed effects to capture the permanent components of capital structure (Lemmon, Roberts and Zender, 2008) as well as a full set of region specific, bank-size specific and capital-ratio specific non-linear time trends that absorb shocks specific to banks in certain regions, banks of certain sizes and banks with certain capital structures. Second, in the spirit of a recent related study (Schepens, 2016), we employ a matching strategy ensuring that identification comes from a comparison of banks, some exposed to a levy and others not, which followed the same pre-levy trajectory in the key outcomes. Third, we include country-specific linear trends that absorb any cross-country differences in secular trends in bank risk unrelated to the levies. Finally, we address the possible endogeneity of bank levies to local market conditions with a placebo test that estimates the effect of bank levies on non-banks and with a robustness test that exploits a key difference in the levy design to effectively compare banks facing a levy directly on debt to banks facing other types of levies.

Measuring the different dimensions of risk is a separate empirical challenge. In our baseline regressions, we measure banks' total risk by their regulatory capital ratio defined as the amount of capital per euro of risk-weighted assets. This is the key variable used by financial regulators to assess the risk of individual banks and it conveniently breaks down into measures of funding risk (capital / total assets) and portfolio risk (average risk weights on assets). These measures suffer from the weakness that the risk weights assigned to banks' assets only imperfectly capture their true risk properties (Elfing, 2016; 
Behn et al, 2016) and may even be subject to deliberate manipulation by banks (Haldane, 2013; Mariathasan and Merrouche, 2014). They also do not account for other types of risk such as liquidity risk and off-balance sheet risk. Faced with these concerns, we also study a number of alternative risk measures.

Our key finding is that the European bank levies induced banks to reduce funding risk, but also to restructure their assets in a way that increased portfolio risk and thus limited the effectiveness of the levies in reducing banks' total risk. Concretely, our preferred estimates suggest that banks exposed to a bank levy raised the ratio of equity to assets by around 0.4 percentage points relative to non-exposed banks (around 0.07 standard deviations), but at the same time raised the average risk weight of their assets by around 2.4 percentage points (around 0.12 standard deviations). While the net effect on the regulatory capital ratio is positive in most specifications, it becomes indistinguishable from zero when we include a full set of controls. The results are consistent with the theoretical view that funding risk and portfolio risk are substitutes: banks appear to shift risk to the asset side of the balance sheet when policy interventions make risk on the liability side less attractive.

Reassuringly, given the conceptual problems with regulatory risk weights as a measure of portfolio risk, most results extend to alternative risk measures. In terms of portfolio risk, we show that the share of impaired loans increases and that the return on trading assets becomes more extreme when banks are exposed to a levy. These results are suggestive of increased risk in the loan portfolio and the trading portfolio respectively and are thus consistent with the estimated increase in risk weights. In terms of total risk, some ambiguity remains. We find that banks exposed to a levy experience a decrease in the volatility of stock market returns suggesting a decrease in total risk; however, we do not find that book returns to equity become less extreme, which is consistent with our preferred estimate of a zero-effect on the regulatory capital ratio. Considering all the evidence, we cannot reject that the net effect of the balance sheet adjustments to the levies was to reduce total risk.

Finally, we explore the heterogeneity in banks' responses to the levies by testing whether the estimated changes in risk differ systematically across banks with different pre-levy regulatory capital ratios. We find that banks that were ex ante more risky 
increased the average risk weight of their assets significantly more when exposed to a levy and therefore also exhibited a smaller increase in the regulatory capital ratio. This finding is of considerable policy relevance since, from a micro-prudential perspective, reducing the risk of banks that are already relatively safe is of limited value whereas it is highly desirable to reduce the risk of banks with a high probability of failure. If, as our empirical results suggest, the corrective effect of bank levies is concentrated among banks that pose no or little threat to financial stability, it reduces the appeal of bank levies as a policy instrument.

The main contribution of the paper is to investigate how bank levies shape funding and portfolio decisions: we show that banks exposed to a levy increase equity funding but also that they to some extent undo the resulting reduction in risk by taking on more risky assets. While it is a well-known theoretical result that banks can neutralize the effect of government interventions by shifting risk between the two sides of the balance sheet, we are not aware of existing papers that document it empirically. Risk shifting has important implications for contemporary discussions about fiscal and regulatory intervention in the financial sector. First, it suggests that the bank levies themselves, which are becoming an integral part of the financial architecture in many countries, are more effective if the levy base is adjusted for portfolio risk. Second, it calls into question the effectiveness of a key innovation in the post-crisis regulatory framework, the leverage ratio, which requires a minimum amount of capital for each unit of assets and thus complements the existing capital requirement formulated in terms of risk-weighted assets. The leverage ratio may force some banks to reduce funding risk; however, our results suggest that the effect on total risk may be limited because banks are likely to substitute funding risk with portfolio risk.

While our results on the shifting of risk within bank balance sheets have broad implications for the design of government interventions in the financial sector, the analysis relates most directly to an emerging literature on bank taxation. Two recent papers studying corporate taxes (Keen and de Mooij, 2016) and mandatory charges financing deposit insurance (Kreicher, McCauley and McGuire, 2013) find that banks' funding structures respond strongly and sharply to changes in fiscal incentives, which is consistent with our results on the bank levies. Another recent paper documents that the 
introduction of a corporate tax shield for equity in Belgium improved the capital ratios of Belgian banks and, moreover, reduced the riskiness of their assets (Schepens, 2016). The paper's finding that funding risk and portfolio risk are complementary goes contrary to our finding that they are substitutes, which begs further research. Finally, there is a small literature on the bank levies, which focus primarily on their incidence and show that they benefit depositors since banks competing for funding not subject to the levies offer higher deposit rates (Kogler, 2016; Buch, Hilberg and Tonzer, 2016), but at the same time harm retail borrowers as the cost of the levies are passed on to customers with low demand elasticity (Kogler, 2016; Capelle-Blancard and Havrylchyk, 2017).

The remainder of the paper is structured in the following way. Section 2 provides background information about the bank levies; Section 3 develops a conceptual framework; Section 4 describes the data; Section 5 discusses the empirical framework; Section 6 presents the results; and Section 7 concludes.

\section{Background}

In the wake of the financial crisis, the IMF promoted levies on banks' borrowing as a tool to increase revenue collection from the financial sector while at the same time contributing to financial stability by incentivizing banks to adopt less risky capital structures. Bank levies of some form have been adopted in a number of countries and are still under consideration in many others. In the U.S., the Financial Crisis Responsibility Fee was proposed numerous times by the Obama administration, but has still not been passed into law.

In this paper, we analyze the effects of 14 bank levies that were implemented by member states of the European Union ("EU") over the period 2009-2012. In the course of 2010, EU legislators discussed the possibility of introducing a harmonized bank levy in all 27 EU countries. When these negotiations were suspended, 14 EU countries decided to adopt bank levies unilaterally while another 13 countries did not proceed with the levies. Eventually, in 2014, the EU passed legislation that requires all its member states to adopt bank levies with the purpose of financing a bank resolution fund.

In the comments to the laws implementing the levies, the objectives stated by the 
legislators were typically to raise government revenue and to reduce risk-taking in the financial sector, mirroring the key benefits highlighted by the IMF (2010). In the U.K., for instance, the dual aim of the legislators was to "ensure that banks make a contribution that reflects the potential risk to the UK financial system and the wider economy from bank failures" and "to encourage banks to move away from riskier funding" (HM Treasury, 2010).

Table 1 describes key characteristics of the 14 bank levies (more details are provided in the Online Data Appendix). ${ }^{1}$ The most common levy design adopted by 11 countries (Austria, Belgium, Cyprus, Germany, Netherlands, Latvia, Portugal, Romania, Slovakia, Sweden and the UK) taxes some measure of bank liabilities. While the levies are conceptually similar, they vary along several dimensions. First, most of the levies fall on total liabilities net of own funds and customer deposits that are guaranteed under a deposit insurance scheme, but two countries (Cyprus and Portugal) include insured deposits in the levy base. Second, most levies treat short-term and long-term liabilities symmetrically, but two countries (Netherlands and the UK) apply a reduced rate to liabilities with a maturity exceeding one year. Third, most of the levies apply a flat rate, but four countries (Austria, Germany, Netherlands and the UK) have a progressive rate structure where small banks are taxed at lower rates than large banks or not taxed at all. Finally, the UK rules have several provisions that narrow the taxable base, which are not found in other countries: most notably, they allow for the netting of gross assets and liabilities against the same counterpart and grant a deduction for highly liquid assets.

Table 1 around here

Most of these departures from the general principle of a flat levy on bank borrowing can be rationalized within a Pigouvian framework: provided that the deposit insurance is correctly priced, there is no rationale for additional taxes on insured deposits; long-term liabilities reduce the exposure to volatile money markets and thus the risk of distress (Perotti and Suarez, 2011); and the distress of large banks is likely to be associated with disproportionately large externalities due to their systemic role. One feature of the

\footnotetext{
${ }^{1}$ Available at the webpage: www.nielsjohannesen.net.
} 
Austrian levy, however, seems to be motivated mostly by other considerations: the levies paid by Austrian banks in 2011-2013 were made with reference to the balance sheet in 2010, presumably to enhance the predictability of the government revenue to be raised by the levy. The fact that the law was passed very close to year-end in 2010 effectively eliminates the scope for behavioral responses to the levy during our sample period.

Three countries (France, Hungary and Slovenia) adopted bank levies that are conceptually quite different from the design described above. In France, the taxable base is the minimum amount of capital necessary to comply with the regulatory requirements. In Hungary, the bank levy falls on total assets net of inter-bank lending. In Slovenia, the taxable base is total assets with no deductions; however, the levy is not due if either the level of lending to the non-financial sector or the growth in lending to the non-financial sector exceeds a threshold. It is not immediately clear how we should expect these three levies to affect banks' funding and portfolio choices. None of them directly change the incentives underlying funding choices and while one should expect the French levy to cause a decrease in portfolio risk, this is not obvious for the Hungarian and Slovenian levies. Because of these ambiguities, our empirical analysis omits the French, Hungarian and Slovenian banks from the sample and focuses on the 11 bank levies that fall on a similar and well-defined measure of bank liabilities.

While most governments motivated the levies with the need to raise more revenue from the financial sector as well as the likely desirable effect of levies on financial stability, the actual use of the revenue varied. In some countries (e.g. Germany), the proceeds went into a bank resolution fund whereas in other countries (e.g. the U.K.) there was no link to specific types of expenditures.

It is important to note that several other policy initiatives aiming to enhance stability in the financial sector may directly and indirectly have affected banks' funding and portfolio choices. First, the new international framework for financial regulation, Basel III, phased in from 2013, increased the minimum capital requirements in terms of riskweighted assets and introduced a minimum leverage ratio in terms of total consolidated assets. It is likely that banks anticipating future regulatory requirements started adopting their capital structure already during our period of analysis. Note, however, that bank capital requirements are regulated at the EU level, hence it seems reasonable to assume 
that two otherwise similar banks located in two different countries within the EU were affected similarly by the regulatory changes. ${ }^{2}$ Second, in the aftermath of the financial crisis many governments intervened in the banking sector by providing distressed banks with new equity and by guaranteeing their debt to third parties. In the countries most adversely affected by the crisis, these measures were very significant in size. In Ireland, for instance, government equity injections accumulated to around $4 \%$ of total bank assets over the period 2008-2011 (European Commission, 2012).

\section{Conceptual framework}

While the main endeavor of the paper is to provide empirical estimates of how banks adjust their funding and asset structures in response to banks levies, this section develops a simple conceptual framework that, briefly and informally, describes the incentives governing bank responses. ${ }^{3}$

\subsection{Funding and asset structure}

We consider banks that are funded with equity, deposits and market debt (such as loans from other financial institutions). The funds are invested in risky assets (such as loans to firms) and risk-free assets (such as government bonds). To comply with financial regulation, banks need at least a minimum level of equity corresponding to a fraction of its risk-weighted assets. Banks that fail to meet the capital requirement are shut down by the financial regulator, which involves a real cost denoted the shutdown cost. If a bank has positive equity when it is shut down, the shareholders bear this cost and creditors are paid back fully. If equity is instead negative at the shutdown, the creditors take a haircut as shareholders are protected by limited liability. However, as depositors are covered by deposit insurance, only debtholders are effectively exposed to this risk.

\footnotetext{
${ }^{2}$ It cannot be excluded, however, that differences in enforcement means that regulation effectively varies across countries.

${ }^{3} \mathrm{~A}$ formal analysis of how bank levies shape the equilibrium on credit markets, notably with a focus on incidence, is presented by Kogler (2016). This model differs from our framework in a number of ways because of the focus on incidence, for instance risk is mostly ignored and the required returns to equity and market debt are assumed to be exogoneous to bank behavior. Important contributions to the literature on bank capital structure in the presence of capital requirements include Koehn and Santomero (1980), Kim and Santomero (1988), Rochet (1992) and Glasserman and Kang (2014).
} 
Investors are generally risk averse so the expected return required by shareholders is higher the less the bank is funded with equity and the more the bank invests in high-risk assets because both raise the volatility of equity returns. Debtholders require higher interest rates when equity is low and assets are risky to compensate for higher expected haircuts. The interest rate required by depositors is independent of bank risk because their deposits are insured.

Banks generally adjust all decision margins, their funding structure as well as their asset structure, to maximize the expected value created for the shareholders. Banks make these choices under ex ante uncertainty about asset returns so choosing a low level of equity or a high share of risky assets makes it more likely that the regulator shuts down the bank ex post because equity has fallen below the required minimum. The shareholder value created by the bank can be stated in the following way:

$\underset{\text { value }}{\text { creation }}=\begin{gathered}\text { asset } \\ \text { income }\end{gathered}-\begin{array}{ccc}\text { funding } & \text { cost } & \text { shutdown } \\ \text { cost }\end{array}$

where asset income is income from loans and securities; funding cost is the expected return required by shareholders and the interest required by debtholders and depositors and shutdown cost is the real cost incurred in case of a shutdown. The expected return required by shareholders is the expected return in the best alternative investment with the same risk and the shareholder value created by the bank is the return over and above this opportunity cost. Limited liability puts a lower bound on value creation, which is not explicit in the expression.

In any optimum where banks are funded with a combination of equity, deposits and debt, the three funding types must be associated with the same marginal cost. ${ }^{4}$ On the one hand, the required return to equity is typically considerably higher than interest rates,

\footnotetext{
${ }^{4}$ In theory, the capital requirement could be a binding constraint implying that marginal costs need not be equalized across funding types and that a levy on debt need not induce substition toward equity. This is indeed the view of some theoretical models. For instance, in the classical work of Koehn and Santomero (1980), equity is costly and capital requirements are binding. Adapting this theoretical framework, Celerier, Kick and Ongena (2018) predict that bank levies have no effect on equity, but induce banks to reduce their lending and rearrange their portfolio of assets. However, it is a striking empirical fact that the vast majority of banks have much more capital than the regulatory requirement suggesting that, at least for that subset of banks, our framework with equalization of marginal funding costs will be of empirical relevance.
} 
which tends to make equity more costly than debt and deposits. ${ }^{5}$ On the other hand, equity lowers the cost of infra-marginal units of funding as well as expected shutdown cost, which tends to make it less costly than debt and deposits. In the bank's optimum, the higher required return to equity is, on the margin, exactly offset by the cost savings created by the lower risk. ${ }^{6}$ Likewise, in the optimum, the two types of assets must deliver the same marginal contribution to bank value. Risky assets are generally associated with higher expected returns than risk-free assets, but also increase the volatility of the bank's income. In the optimum, the higher expected return to risky assets is, on the margin, exactly offset by higher funding and shutdown costs.

\subsection{Responses to bank levies}

Starting from such an optimum, the introduction of a levy on debt induces banks to adjust both their funding structure and their asset structure. On the funding side, the levy introduces a wedge between the marginal cost of debt on the one hand and the marginal cost of equity and deposits on the other. This induces substitution from debt to equity and deposits until marginal costs are again equalized across the three types of funding.

The incentives to take risk on the asset side of the balance sheet are not changed directly by the introduction of a bank levy, but indirectly by the adjustment on the funding side. The question is whether funding risk and portfolio risk are substitutes, so that an increase in equity is accompanied by substitution toward risky assets, or complements, so that the substitution on the asset side is rather toward risk-free assets. Since the funding structure has no bearing on asset income, this, in turn, depends on whether the reduction in funding risk makes portfolio risk more or less costly on the margin.

As it turns out, there is no unambiguous answer to that question. On the one hand,

\footnotetext{
${ }^{5}$ Based on the CAPM model, King (2009) estimates that the required real return to bank equity was $6.6 \%$ in the U.K, $7.2 \%$ in France and $9 \%$ in Germany in the years before the financial crisis. With inflation rates around $2 \%$, this implies a nominal return of around $10 \%$. By comparison, both money market borrowing rates and deposit rates were around $2-4 \%$ in the same period, but have fallen to levels near or below zero in more recent years. At least part of the cost advantage of deposits in terms of low interest rates is offset by the operational costs of servicing the current accounts of individual customers.

${ }^{6}$ For scholars advocating higher capital requirements, it is a key argument that differences in required returns across different types of funding do not reflect differences in private costs, let alone social costs (Admati et al., 2010).
} 
at higher levels of equity, a marginal increase in portfolio risk is likely to create a smaller increase in the probability to fall below the required level of capital and is therefore associated with a smaller increase in costs. Intuitively, the negative return required to reach the minimum level of capital is more extreme when the bank is more capitalized and thus associated with a lower probability density under most plausible distributions of asset returns. On the other hand, at higher levels of equity, shareholders are more likely to bear the downside risk of the bank's portfolio choices, which means that an increase in portfolio risk is associated with a larger increase in their required return. The effect on the bank's total funding cost is partly neutralized by debtholders who require less compensation for portfolio risk when equity is high, but not fully neutralized because the interest rates on insured deposits are risk invariant. The former mechanism implies that a decrease in funding risk induced by the levy should be accompanied by an increase in asset risk $;^{7}$ the latter mechanism that it should be accompanied by a decrease in asset risk. $^{8}$

Finally, banks choose not only the composition of their funding and their assets, but also the overall size of the balance sheet. The levy directly increases the marginal cost of one type of funding, market debt, and after the adjustments on the funding side, marginal costs will be equalized at a higher level. The increase in marginal funding costs should induce banks to reduce the size of the balance sheet by shedding the assets with the lowest contribution to bank value.

\subsection{Price effects}

So far, we have described the shifts in banks' demand for funds of different types as well shifts in banks' supply of funds to different types of investors in response to a bank levy. While we allowed prices in the capital market, i.e. required returns and interest

\footnotetext{
${ }^{7}$ Substitution between funding risk and asset risk also emerges in other types of models. First, as shown by Koehn and Santomero (1980), if bank managers act as risk averse maximizers of expected utility, a (mandated) increase in bank capital lowers the marginal disuility of risk, which induces managers to invest in more risky assets. Second, as shown by Devereux (2014), if banks are maximizing overall risk subject to regulatory constraints, so that they are effectively choosing between combinations of funding and asset risk that leave them exactly at the required ratio of capital to risk-weighted assets, a levy that raises the cost of debt induces banks to choose a different combination with less funding risk and more asset risk.

${ }^{8}$ This mechanism plays an important role in several theoretical models of bank risk including Allen, Carletti and Marquez (2011).
} 
rates, to vary with bank risk, we implicitly assumed that the prices were unchanged for a given level of risk. However, if many banks are affected by the levies and shift their demands and supplies in the same direction, it may have sizable effects on equilibrium prices, which would again have feedback effects on banks' choices.

Specifically, the reduced demand for market debt may lower the interest rate required by debtholders for a given risk, which attenuates the substitution away from this type of funding. Conversely, substitution toward equity and deposits, may drive up required returns to equity and deposit rates. Finally, to the extent that portfolio risk and funding risk are substitutes (complements) so that the levy increases (reduces) the demand for risky assets, we should expect a decrease (increase) in the expected return to risky assets. ${ }^{9}$

It is well-known from the analysis of tax incidence that the magnitude of such price effects depends, among other things, on demand and supply elasticities (Fullerton and Metcalf, 2002). At one extreme, it is possible that the (pre-levy) equilibrium interest rate on debt falls by the full amount of levy. This occurs, for instance, if the supply of debt to banks is completely inelastic, in which case banks' funding and asset structures would remain exactly the same as before the levy. At the other extreme, it is possible that the (pre-levy) equilibrium interest rate on debt remains unchanged by the levy. This occurs, for instance, if the supply of debt to banks is perfectly elastic, in which case bank levies would be accompanied by relatively large changes in banks' funding and asset structures along the lines of the analysis above. In any case, our empirical analysis studies the effect of levies on observed bank outcomes, which includes the shift in banks' demand and supply at given (pre-levy) prices as well as the effect working through changes in equilibrium prices.

\footnotetext{
${ }^{9}$ Kogler (2016) and Buch, Hilberg and Tonzer (2016) provide empirical evidence that levies on bank debt are associated with an increase in the observed deposit rate, which is consistent with substitution on the funding side, whereas Kogler (2016) and Capelle-Blancard and Havrylchyk (2017) show that the cost of levies are passed on to borrowers in the form of higher lending rates.
} 


\section{Data}

\subsection{Sources}

Our main source of data is Bankscope, which contains information on balance sheets, income statements and in many cases regulatory reports taken from banks' annual reports. ${ }^{10}$ We limit our sample to banks for which information on the regulatory capital ratio and the stock of regulatory capital is available since this information is necessary to compute basic risk measures. This information is available for around $40 \%$ of banks accounting for around $65 \%$ of all bank assets. ${ }^{11}$ The main explanatory variables concern the bank levies. Combining hand-collected information from national legal texts, a survey by KPMG (2012) and other notes by professional tax advisers in the relevant countries, we have created a comprehensive database with detailed information on the bank levies. The database is summarized in Table 1 and the full database is available in the Online Data Appendix. Finally, we have collected a number of control variables, including inflation rates and real GDP growth rates from Eurostat; statutory corporate tax rates from the OECD Tax Database and the KPMG Corporate and Indirect Tax Survey 2011; information on government recapitalizations of distressed banks and government guarantees of bank debt from the European Commission (2012); and a list of the European banks faced with temporary additional capital requirements from the European Banking Authority (2011). These data are all available and documented in the Online Data Appendix.

\subsection{Summary statistics}

Table 2 summarizes key characteristics for our sample of 2,754 banks from 27 European countries for the time period 2004-2012 in Columns (1)-(3). ${ }^{12}$ Panels A-C describe the balance sheets and profitability of banks, Panel D describes the range of variables we use

\footnotetext{
${ }^{10}$ Since the subsidiaries of foreign banks are generally treated as stand-alone banks under the levies, we also treat them as such in the empirical analysis, e.g. the UK subsidiary of a German bank is coded as a UK bank and its balance sheet is not consolidated with the parent.

${ }^{11}$ Strictly speaking, we cannot be certain that the results extend to banks outside the sample due to potential selection issues. However, we find very similar results when we, for each outcome, run the regressions with the largest possible sample.

${ }^{12}$ Croatia joined the EU in 2013, raising the number of member states to 28 , and is not included in the sample.
} 
to characterize bank risk (explained in detail below) and Panel E describes our control variables at the country level.

Table 2 around here

We report the summary statistics separately for four subsamples in Columns (4)(11). The key distinction in our empirical analysis is between banks that are subject to a levy and banks that are not. We therefore split the bank sample on whether the home country introduced a bank levy at some point during the period 2009-2012. As shown in columns (4)-(7), banks in levy countries and non-levy countries are reasonably comparable in terms of observable characteristics although banks in levy countries are larger, rely more on deposits for financing and have somewhat less risky assets than banks in other countries. In addition, the paper investigates whether bank responses to the levies are correlated with the extent to which they were constrained by regulation. For this purpose we split the sample according to whether the ratio of regulatory capital to risk-weighted assets was above or below the sample median in 2008. As reported in columns (8)-(11), banks with high regulatory capital ratios are much smaller and have slightly less risky assets than banks with low regulatory capital ratios.

\section{$5 \quad$ Empirical strategy}

\subsection{Estimation and identification}

Our main research question is whether the European bank levies have affected banks' risk-taking along various dimensions. We study that question by estimating variants of the following model:

$$
r i s k_{i t}=\alpha+\beta l e v y_{i t}+\gamma_{i}+\theta_{t}+\phi \mathbf{X}_{i t}+\psi \mathbf{Z}_{c t}+\epsilon_{i c t}
$$

where risk $_{i t}$ measures the risk of bank $i$ at time $t$; levy $y_{i t}$ measures exposure to a bank levy; $\gamma_{i}$ denotes bank fixed effects, $\theta_{t}$ denotes time dummies and $\mathbf{X}_{i t}$ and $\mathbf{Z}_{c t}$ are vectors of bank-level and country-level control variables. Bank fixed effects absorb all crosssectional variation so the levy variable is identified solely by changes in the dependent 
variable. We are essentially testing whether banks that were exposed to a bank levy changed their risk relative to other banks experiencing similar changes in bank-level and country-level controls.

Identification requires the assumption that the risk of banks exposed to a bank levy would have evolved in the same way as the risk of other banks absent the levies. To strengthen the credibility of this assumption, we enhance the comparability of exposed banks and the unexposed banks to which they are compared in three distinct ways.

First, in the spirit of Schepens (2016), we employ a matching procedure under which the effect of levies is identified from a comparison of banks with similar pre-levy trends in their risk outcomes. This ensures that any post-levy divergence between exposed and nonexposed banks cannot be ascribed to a difference in the underlying trend. In practice, we implement the matching with a weighting scheme adopted from Yagan (2015). For each bank exposed to a levy, we compute the growth rate in each of the three risk outcomes - funding risk, portfolio risk and total risk (see details about measurement below) - over the two years before levy exposure. We then determine the quintiles of these three growth rates and use them to define 125 groups (five quintiles by three growth rates) within which banks have roughly similar pre-levy growth rates in all three risk outcomes. Finally, we allocate non-exposed banks to the same groups and assign regression weights to them that balance the total weight on exposed and non-exposed banks within each group. Concretely, if there are 10 exposed banks and 20 non-exposed banks in a given group, we assign the weight 0.5 to the non-exposed banks so that there is total weight of 10 on both types of banks. This procedure ensures that each exposed bank is effectively matched with a non-exposed bank on a similar pre-levy trajectory in the regressions.

Second, we introduce a comprehensive set of non-parametric controls that serve to absorb unobserved shocks to the risk outcomes. Specifically, we include interactions between time dummies on the one hand and indicators of bank size, regulatory capital and geographic region on the other. The bank size indicator refers to the quintiles of the distribution of total assets (measured prior to the levies); the regulatory capital indicator refers to the quintiles of the pre-levy distribution of regulatory capital ratios (measured prior to the levies); and the indicator of geographic region refers to Southern, 
Eastern, Central and Northern Europe. ${ }^{13}$ With this set of bank size-specific, capital ratio-specific and region-specific non-linear trends, our estimates are effectively identified from a comparison of banks that have roughly the same size and capital structure and are located in the same geographic region within Europe.

Third, we introduce interactions between country dummies and a linear time trend. While cross-country differences in the level of bank risk are fully absorbed by the bank fixed effects, including country-specific linear trends implies that we are also effectively absorbing country-level differences in the secular trend in bank risk.

It should be noted that the effect of the levies would still be statistically identified if the model were further augmented with interactions between country dummies and time dummies. Such country-specific non-linear trends would absorb any unobserved countrylevel shocks to bank risk and identify the effect of levies exclusively from within-country comparisons of banks facing different marginal levy rates. While attractive in principle, this identification strategy is problematic in practice for at least two reasons. First, it requires exact measurement of marginal levy rates; in practice, we are likely to measure these rates with considerable because of the discrepancy between the accounting categories we observe in our data and the legal categories that define actual levy payments (see section 5.2 below). Second, it requires a large number of banks within each country that face different tax incentives but are similar in other respects; in the real world where there is a relatively small number of highly heterogeneous banks, within-country comparisons of banks facing different marginal levy rates in practice amount to comparisons of banks that are quite different in size, capital structure and other important dimensions. For these reasons, we follow the leading papers in the literature and identify from cross-country differences in government policies (Schepens, 2016; Keen and de Mooij, 2016) while controlling for confounding factors with a matching procedure and a comprehensive set of non-parametric controls.

\footnotetext{
${ }^{13}$ We define four regions. Eastern Europe is Poland, Estonia, Latvia, Lithuania, Czech Republic, Slovakia, Slovenia, Hungary, Romania and Bulgaria; Southern Europe is Spain, Portugal, Greece, Italy, Cyprus and Malta; Northern Europe is the UK, Ireland, Denmark, Sweden, Finland; Central Europe is Austria, Germany, Netherlands, Belgium, France and Luxembourg. Each of these regions includes at least one country that has introduced a levy and at least one country that has not.
} 


\subsection{Measurement}

We study three dimensions of risk: total risk, which in turn depends on funding risk, the risk deriving from financing with debt, and portfolio risk, the risk deriving from investments in risky assets. While the different dimensions of bank risk are conceptually quite clear, measurement represents a serious challenge, which we discuss in detail in this section.

\section{Total risk}

Our baseline measure of total risk is the regulatory capital ratio defined as the amount of total regulatory capital held by the bank per euro of risk-weighted assets. This ratio effectively combines measures of funding risk (capital / total assets) and portfolio risk (average risk weight of assets) and is the key variable used by financial regulators to assess the risk of individual banks. From a practical perspective, an important advantage of this measure is data availability: the regulatory capital ratio is reported in financial statements by more than 2,700 European banks during our sample period.

It is well-known, however, that regulatory risk weights are far from perfect measures of true portfolio risk. The risk weights set directly by financial regulators apply to broad asset classes and thus capture portfolio risk in a very crude way. Since the adoption of the Basel II agreement, many banks have relied on their own estimates of asset risk, but some commentators have expressed concern that the use of internal risk models allows banks to effectively circumvent regulatory capital requirements by understating the risk of their portfolio (Haldane, 2013), a notion that has found some support in recent academic work (Mariathasan and Merrouche, 2014; Elfing, 2016; Behn et al, 2016). If regulatory risk weights can be manipulated by banks, it is unclear whether an observed improvement in a bank's regulatory capital ratio reflects a reduction in its real risk or a change in the (costly) effort exerted to manipulate risk weights. Despite the weaknesses of this measure, regulatory risk weights have been used to approximate portfolio risk in the literature on bank responses to financial regulation (e.g. Rime, 2001) and taxation (Keen and de Mooij, 2016).

To address concerns about the regulatory capital ratio as a measure of total risk, we complement the analysis with two alternative measures. First, we use the standard 
deviation of the daily stock return, which is available for the subsample of banks that is listed on a stock exchange. This is one of the most common measures of bank risk (e.g. Laeven and Levine, 2009; Pathan, 2009; Ellul and Yerramilli, 2013; Cheng, Hong and Scheinkman, 2015). Its main drawback is low coverage: stock prices are only available for around 120 European banks. Second, we develop a measure of total risk based on book returns to equity, which is available for the full sample of banks. The main constraint is that we only have annual accounting information and typically only observe banks for two years after the introduction of the levies; hence, we do not have sufficient observations to compute and compare bank-level volatility of returns before and after the levies. Instead, we base our inference on changes in the cross-sectional distribution of returns. Specifically, we compute the absolute distance between a bank's own return to equity and the median return to equity within a narrow reference group of banks belonging to the same size decile, the same capitalization decile and the same geographical region within Europe and use this distance measure as dependent variable. Intuitively, banks with less risk should on average experience less extreme returns to equity, so if the levies decreased risk, we should observe that banks exposed to the levies experienced returns closer to the reference level relative to their own pre-levy volatility (captured by bank fixed effects) and relative to the general time trend in volatility (captured by time dummies). ${ }^{14}$

\section{Portfolio risk}

Our baseline measure of portfolio risk is the ratio of risk-weighted assets to total assets or, equivalently, the average regulatory risk weight assigned to the bank's assets. As noted above, risk weights are potentially prone to strategic manipulation by banks and we therefore also employ two alternative measures. First, we use the change in the stock of impaired loans measured relative to the value of all loans. Intuitively, if banks increase risk in their loan portfolios by giving credit to more projects with high yields and a high risk of default, we should observe an increase in impaired loans on their balance sheets. Second, we develop a measure of risk that captures the volatility of the return in banks'

\footnotetext{
${ }^{14}$ An alternative book measure of total risk is the z-score defined as the return on assets plus the capital-asset ratio divided by the standard deviation of asset returns (see, for example, Laeven and Levine, 2009; Pathan 2009; Houston et al, 2010; and de Haan and Poghosyan, 2012). Several years of data are required to compute the standard deviation of asset returns, which makes the measure unsuited for our purposes.
} 
trading portfolios: the absolute distance between a bank's own return to securities and derivatives and the median return within a narrow reference group of banks belonging to the same size decile, the same capitalization decile and the same geographical region. Intuitively, if a group of banks increase risk in their trading portfolios, we should observe that the return realized in that portfolio, on average, is further away from the reference return.

\section{Funding risk}

Our measure of funding risk is the ratio of equity to total assets both measured at book value. Since levies due are always defined with reference to the balance sheet, book values are more appropriate than market values in this context. Moreover, book values of equity and total assets are available for all banks in the sample and therefore do not cause the same severe sample attrition as market measures.

\section{Levies}

Drawing on the database with detailed information about the bank levies, we construct two variables to measure the incentives facing banks. First, we construct a dummy variable for the existence of a bank levy at the country-year level. ${ }^{15}$ Second, we construct a measure of the marginal levy rate, which we define as the additional levy cost associated with a unit increase in taxable liabilities, at the bank-year level. In principle, this measure fully captures the within-country and between-country variation in marginal incentives across banks and allows us to directly estimate the tax responsiveness of the outcomes of interest. To construct the variable, we approximate the levy base for each individual bank and year on the basis of the balance sheet information and the legal definition of the levy base and identify the applicable marginal levy rate as the increment in the levy bill that would follow from a unit increase in short-term debt. This procedure is similar to the simulation of effective marginal tax rates in studies of income taxes and transfers. Details of the construction of marginal levy rates are available in the Online Data Appendix.

\footnotetext{
${ }^{15}$ Note that since we are interested in behavioral responses to the levies and the Austrian levy was effectively retroactive for 2011-2013, we code the dummy variable zero for this country.
} 


\section{Winsorizing}

Some variables are not naturally bounded and may take extreme values. For instance, the ratio of equity to assets approaches negative infinity for troubled banks with few assets and large liabilities. To prevent the results being driven by extreme values, we conservatively winsorize these variables at the $5 \%$ and $95 \%$ level. Our results are robust to other ways of handling extreme observations.

\section{Results}

This section presents our results. Unless indicated otherwise, the sample includes banks in the 27 EU countries except France, Hungary and Slovenia and the sample period is 2004-2012. Regression coefficients are reported with robust standard errors clustered at the country-year level and at the bank level. ${ }^{16}$

\subsection{Main results}

Table 3 reports the results obtained from estimating a parsimonious variant of (1) with bank fixed effects, time dummies and a small set of basic controls. The dependent variables are our baseline measures of funding risk, portfolio risk and total risk. For each dependent variable we present both unweighted and weighted regressions, where weighting matches each bank exposed to a bank levy to a non-exposed bank with similar pre-levy trends in the three risk outcomes.

Columns (1)-(2) suggest that bank levies had a strong negative effect on funding risk. In the unweighted regression, the coefficient on levy implies that banks exposed to the bank levies increased equity-asset ratios by around 1.3 percentage points relative to nonexposed banks; however, the estimated effect drops to around 0.9 percentage points in the weighted regressions where we compare banks on similar pre-levy trajectories. Columns (3)-(4) suggest that at least some of the reduction in funding risk was offset by an increase in portfolio risk. The results from the unweighted regression imply that banks changed their asset portfolios in response to the levies in such a way that the average risk weight increased by around 4 percentage points. Again, the estimated effect is somewhat smaller,

\footnotetext{
${ }^{16}$ Two-way clustering is implemented with REGHDFE in stata.
} 
less than 3 percentage points, when the matching procedure is employed. Columns (5)-(6) suggests that bank levies on balance reduced the total risk of banks. The results from the unweighted regressions imply that the bank levies induced banks to increase regulatory capital ratios by around 0.9 percentage points on average while the corresponding results from the weighted regressions imply an increase of around 0.6 percentage points. The findings suggest that the unweighted regressions may overstate the effects of the levies by comparing banks on different pre-levy trajectories.

Table 3 around here

The covariates have similar effects in the weighted and unweighted regressions. The negative coefficient on assets in Columns (1)-(2) suggests that expansions of bank balance sheets tend to be financed with debt, which is consistent with the findings in Adrian and Shin (2010), while the negative coefficient in Columns (3)-(4) suggest that marginal funds are invested in assets with less-than-average risk. The positive coefficient on profitability in Columns (1)-(2) and (5)-(6) partly reflects that profits in a given financial year mechanically translate into retained earnings on the end-of-year balance sheet and thus, everything else equal, increase the equity and capital ratios. The country-level variables, inflation, GDP growth and corporate tax rate, do not seem to affect bank risk during our sample period.

Figures 1-3 illustrate the results from an event-study version of the weighted regressions in Columns (2), (4) and (6). Instead of a dummy variable indicating that a bank levy is in place, the event study specification includes a set of dummy variables indicating the year relative to the introduction of a bank levy. The coefficients on these event time dummies thus capture the risk dynamics of banks exposed to a levy relative to nonexposed banks. For all three outcomes, the two groups of banks are on broadly the same trajectory before the introduction of the bank levies. This reflects that the matching procedure is working: the weighted regressions are effectively comparing banks exposed to a levy to non-exposed banks with similar pre-levy dynamics in risk. More interestingly, there is a clear divergence in all three outcomes when levies are introduced: the equity ratio increases by around 0.8 percentage points in the year levies are introduced and by an additional 0.2 percentage points in the following year; the average risk weight increases 
by around 1 percentage point in the first year and by an additional 0.3 percentage points in the second year; and the regulatory capital ratio increases by around 0.6 percentage points in the first year and remains at this higher level in the second year.

Figures 1-3 around here

The most important concern with the baseline results is that they may be partly driven by unobserved shocks coinciding with the introduction of the banks levies. Table 4 reports the results from a number of extensions to the baseline model that aim to estimate the effect of the banks levies while allowing for various types of shocks. For ease of comparison, Column (1) reiterates the main coefficients of interest from the unweighted baseline specification in Table 3 and each subsequent column represents an extension of this specification. Panel A presents results for funding risk, Panel B for portfolio risk and Panel $\mathrm{C}$ for total risk. The coefficients on the covariates are not reported.

Table 4 around here

First, large banks differ from small banks in a number of ways that may affect how their risk outcomes respond to changes in the macro-economic environment; for instance, larger banks have better access to capital markets, employ more sophisticated risk management tools and are more likely to benefit from implicit government guarantees (Iyer et al., 2016). Column (2) accounts for size-specific shocks by including interactions between time dummies and indicators of the quintiles in the distribution of total assets (measured prior to the introduction of the levies), which implies that the effect of levies is identified by a comparison of banks of a roughly similar size. The estimated effects of the bank levies are almost unchanged by this extension suggesting that unobserved size-specific shocks to risk outcomes do not correlate with the levies.

Second, the most risky banks faced strong pressure from markets as well as regulators to reduce risk in the wake of the financial crisis and may therefore have been on a distinct trajectory during the time period where bank levies were introduced. Column (3) accounts for capital ratio-specific shocks by including interactions between time dummies and indicators of the quintiles in the distribution of regulatory capital ratios (measured 
prior to the introduction of the levies) and thus identifies the effect of levies by a comparison of banks with a similar ex ante level of total risk. This extension also has a rather small effect on the point estimates.

Third, the sovereign debt crisis after the financial crisis affected banks in Europe in a highly asymmetric fashion with banks in Southern Europe, notably in Greece, Portugal, Spain and Italy, suffering greater losses than banks in other parts of Europe. Column (4) accounts for region-specific shocks to banks by including interactions between time dummies and indicators of four geographical regions. With this extension, the effect of the bank levies is identified solely from comparisons of banks in the same region, of which some are exposed to a levy and others are not. The point estimates drop considerably in this specification, notably the implied increase in the equity ratio falls by more than half relative to the baseline estimates and the implied increase in the regulatory capital ratio becomes economically and statistically insignificant. These results suggest that the baseline estimates of the effects of bank levies partly reflect region-specific shocks other than the bank levies themselves; for instance, if banks in Southern Europe were suffering greater losses during the sovereign debt crisis and at the same time were less likely to be exposed to a levy, this may create a spurious positive correlation between the introduction of levies and equity ratios.

Fourth, banks in different countries may have different secular trends in risk outcomes. Column (5) accounts directly for such differential underlying trends by including interactions between a linear trend and country dummies. With the levy variable being identified conditional on country-specific linear trends, the estimated effect on portfolio risk drops by more than half compared to the baseline specification, but remains statistically significant. This suggests that the introduction of bank levies may indeed correlate with underlying country-level trends in portfolio risk and that this correlation causes the baseline estimate of the change in portfolio risk to be mis-measured.

Fifth, there were several other governments interventions in the banking sector besides the bank levies during the sample period. Column (6) controls directly for those by augmenting the model with the following three variables: (i) cumulative government spending on bank recapitalizations measured as a fraction of total bank assets (using data from European Commission, 2012); (ii) the share of bank assets invested in trad- 
ing securities, which became subject to increased capital coverage requirements in 2011 (Bankscope) and; (iii) a dummy variable coded one for banks that temporarily became subject to stricter capital requirements in 2011 (European Banking Authority, 2011). The coefficients on the levy variable barely changes, which suggests that other government interventions were essentially orthogonal to the bank levies.

Finally, we present results from regressions that include all these additional controls at the same time in Columns (7) and (8); the former based on standard unweighted panel regressions and the latter employing the regression weights that implement our matching scheme. These models simultaneously account for a host of observed and unobserved shocks and the results represent our preferred estimates of the causal effects of the levies on bank risk.

The results confirm that banks responded to the introduction of the levies by reducing funding risk; controlling for a large number of potentially confounding factors, banks exposed to the bank levies increased equity-asset ratios by around 0.4 percentage points relative to non-exposed banks. The estimated effect on the equity-asset ratio corresponds to around $5 \%$ at the sample mean or around 0.07 standard deviations. The results also suggest that the reduction in funding risk was accompanied by an increase in portfolio risk; banks changed their asset portfolios in response to the levies such that the average risk weight increased by around 2.4 percentage points. This represents evidence that banks shifted risk to the asset side of the balance sheet in response to a policy intervention that made risk on the liability side less attractive. The estimated effect on the average risk weights corresponds to around $4 \%$ at the sample mean or around 0.12 standard deviations. With the full set of controls, we cannot reject that the increase in portfolio risk was large enough to fully offset the decrease in funding risk so that the net effect of the bank levies on total risk was zero.

\subsection{Placebo tests}

A specific concern not addressed in the previous section is the possibility that the bank levies were endogenous to local market conditions. For instance, bank levies may have been considered a more attractive policy in countries where banks were recovering quickly from the financial crisis and therefore able to bear an additional fiscal burden; in countries 
where the supply of equity capital was sufficient to allow banks to reduce debt financing; or in countries where markets and policy makers were particularly averse to leverage. In all of these cases, one may be concerned that the increase in banks' equity ratios coincided with the implementation of the levies, but were really caused by other factors. We address this concern in two distinct ways.

First, we estimate the effect of bank levies on the equity-asset ratios of non-financial firms. The sample is drawn from the database Orbis and consists of the largest firms in each EU country while setting the size threshold so as to obtain the same number of nonfinancial firms in each country in 2008 as we have in the baseline sample of banks. For non-financial firms, the incentives underlying the choice between debt and equity were not affected by the levies; however, they were subject to the same local market conditions as banks. Hence, if the correlation between the introduction of bank levies and increases in banks' equity ratio is spurious, we should expect to see similar increases in the equity ratio of non-banks. Figure 4 presents the analogue of the event-study regression underlying Figure 1 for non-financial firms. Clearly, their equity ratio did not increase in the same way as that of banks around the introduction of the levies, which supports the notion that the estimates presented in the previous section capture the causal effect of the levy.

Second, we use that four countries, Austria, France, Hungary and Slovenia, adopted levies that did not create a direct incentive for banks to reduce their borrowing; for this reason, banks in these countries do not enter the estimating sample used in the previous section. Now, we exploit this key difference in the design of the levies to effectively compare banks in countries whose levies directly penalize debt financing to banks in countries whose levies do not. Specifically, we estimate the event-study model while restricting the sample to countries that adopted some kind of levy in the period 20092012 and let the levy dummy indicate only those levies that fall directly on bank debt. If the estimates presented in the previous section were in fact caused by the local market conditions that induce governments to adopt bank levies, we should expect no difference between banks subject to the two types of levies. Figure 5 presents the analogue of Figure 1. The equity ratio of banks subject to a levy directly on bank debt increased significantly relative to banks subject to another type of levy, which represents further evidence that our results capture bank responses to a policy change that made debt less 
attractive relative to equity.

Figures 4-5 around here

\subsection{Marginal levy rates}

This section reiterates part of the analysis from above while using the marginal levy rate rather than the levy dummy as a measure of exposure to bank levies. In principle, this offers two advantages. First, it exploits another dimension of the policy variation embedded in the wave of bank levies: the differences in rate structure within and between countries. Second, the estimates directly express economically meaningful parameters, such as the sensitivity of the capital structure with respect to the marginal levy rate on debt, which enhances the comparability with related studies of taxation and bank risk.

It is important to note, however, that the marginal levy rate often depends on bank characteristics and is therefore most correctly treated as an endogenous variable. For instance, the marginal levy rate depends on bank size in Germany and several other countries and on the debt maturity in the UK and the Netherlands. To address this issue, we instrument each bank's marginal levy rate with the country's top marginal levy rate. The instrument is clearly exogenous to any behavioral responses to the levies and is very strongly correlated with actual levy exposure. This instrumentation strategy is used by many existing studies to address the endogeneity of personal income taxes (e.g. Burman and Randolph, 1994). Moreover, as noted above in section 5.1, the measurement of the marginal levy rate is subject to error; however, instrumenting it alleviates this problem (Sargan, 1958).

Table 5 presents results from reduced-form regressions where the top marginal levy rate is used directly as an explanatory variable (Columns 1-3) and instrumental variable regressions where the top marginal levy rate instruments for the marginal levy rate (Columns 4-6). We start with the most parsimonious variant of the standard panel model and then add regression weights (as in Table 3) and a full set of controls (as in Table 4).

The qualitative patterns are consistent with the previous results. Both the matching procedure and the comprehensive set of controls reduce the estimated coefficients markedly; however, even in the most saturated specifications, we find a significant de- 
crease in funding risk as well as a significant increase in portfolio risk. The point estimate of the effect on total risk is statistically and economically insignificant suggesting that the shifting of risk from the liability side of the balance sheet to the asset side in response to the bank levies left total risk unaffected.

Table 5 around here

The results allow for a quantitative comparison of the estimated parameters with related papers; notably Keen and de Mooij (2016) who study the effect of corporation taxation on banks' capital structure. Their key estimate suggests that a 1 percentage point increase in the corporate tax rate reduces the equity-asset ratio by around 0.25 percentage points. By comparison, our preferred estimate suggests that a levy of 0.1 percent increases the equity-asset ratio by 1.4 percentage points (Column 6). Taking these estimates at face value, a 0.1 percent bank levy has roughly the same effect on the equity-asset ratio as a reduction in the corporate tax rate of 5-6 percentage points.

To further assess whether the two estimates are consistent with the same underlying responsiveness to tax incentives, note that a levy of 0.1 percent increases the annual cost of a euro of debt by 0.1 cent. Assume that banks borrow at 2 percent such that each percentage point reduction in the corporate tax rate increases the after-tax cost of a euro of debt by 0.02 cent. This implies that a reduction in the corporate tax rate of 5 percentage points increases the after-tax cost of a euro of debt by 0.1 cent. Hence, under the assumption of a 2 percent borrowing rate, our preferred estimate implies a similar sensitivity of equity-asset ratios with respect to tax incentives as found by Keen and de Mooij (2016). We note that the estimates reported by Keen and de Mooij (2016) are similar in size to the consensus estimates in a large literature studying the effect of taxation on the capital structure of non-financial firms (de Mooij, 2011). Our results thus lend further credence.to the conjecture that capital structures exhibit roughly the same responsiveness to tax incentives across financial and non-financial firms.

\subsection{Alternative risk measures}

This section investigates whether the baseline results are robust to using alternative measures of total risk and portfolio risk given the weaknesses of the main measures 
discussed in detail above. The results are reported in Table 6 .

In Panel A, we first show that the volatility of banks' daily stock return decreases significantly when they are exposed to a bank levy, which is suggestive of a decrease in total risk. This result emerges in the parsimonious variant of the standard panel model (Column 1) and remains when we add regression weights (Column 2) and a comprehensive set of controls (Column 3). ${ }^{17}$ The point estimate of around -0.75 percentage points in the last specification is quite large compared to a standard deviation of the daily stock returns of around 3.5 percentage points for the average bank in the pre-levy period. However, the next set of results indicates that book returns to equity do not come closer to the reference group when banks are exposed to a levy. This result emerges consistently across all three specifications (Columns 4-6).

Table 6 around here

This first finding supports a more positive view on the ability of levies to curb risk in the financial sector than the baseline results. Note, however, that the results are obtained in the relatively small subsample of banks that are listed on a stock exchange and do not necessarily generalize to the full sample. Indeed, re-estimating the model with the regulatory capital ratio as a measure of total risk, but constraining the sample to banks entering the estimating sample in Column 3 yields a sizable, albeit not statistically significant, coefficient on levy of around 0.3 percentage points (results not reported). This is suggestive that the discrepancy between the results with the two different measures of total risk is at least partly due to differences in the sample. The second finding is consistent with the baseline result that levies have no detectable effect on banks' total risk in the full sample.

In Panel B, we first show that the return in bank's trading portfolios move further away from the reference group when banks are exposed to a levy. In the parsimonious specifications (Columns 1-2), the point estimate on levy is positive but statistically insignificant; however, when the model is saturated with more controls (Columns 3), it becomes strongly statistically significant. The point estimate of 0.034 corresponds to

\footnotetext{
${ }^{17}$ Note that this specification does not include country-specific linear trends; the trends are difficult to identify separately from levy effects in the very short sample available for the volatility measures, 2008-2012, and with a relatiely small number of observations, slightly more than 100 banks.
} 
around 0.15 standard deviations. The next set of result shows that the introduction of levies is also accompanied by an increase in impaired loans (Columns 4-6). The increase of 0.0014 found in the most saturated model corresponds to around 0.18 standard deviations.

The finding that banks exposed to a levy on average realize more extreme returns on their securities and derivatives and experience an increase in loan impairments is suggestive that levies induce banks to increase the riskiness of their trading positions as well as their loan portfolios. This is clearly consistent with the increase in average asset risk weights reported in section 6.1 .

Finally, we explore the dynamics in these alternative risk measures by estimating event-study versions of the models following the procedure explained in section 6.1. Figure 6 shows that the volatility of the stock market returns of exposed banks (measured relative to non-exposed banks) was significantly lower after the introduction of the levies than before whereas Figure 7 shows that the absolute distance to the reference book return on equity did not change significantly around levy exposure. Figures 8 and 9 provide further evidence that the increase in the riskiness of trading positions and loan portfolios was indeed caused by the introduction of the levies: these measures of portfolio risk evolved very similarly for exposed and non-exposed banks between periods t-4 and t-1 and then diverged rather sharply.

Figures 6-9 around here

\subsection{Heterogeneous effects}

The results above have shown that, for an average bank, levies reduce the funding risk, but that a corresponding increase in portfolio risk at least partly neutralizes the effect on total risk. In this section, we ask whether these effects differ systematically between banks with ex ante different levels of total risk. This question is of considerable policy relevance since, from a micro-prudential perspective, it is much more important to reduce the total risk of high-risk banks than low-risk banks.

We implement this idea by augmenting the models with the interaction between the levy dummy and the regulatory capital ratio (measured in 2008 and therefore exogenous 
to later changes in risk induced by the levies themselves). From each bank's regulatory capital ratio, we have subtracted the median regulatory capital ratio (around 14\%) so that the main effect can be interpreted as the treatment effect at the median. The results are reported in Table 7.

The first set of results explores the heterogeneous effect of the levies on funding risk. In the parsimonious unweighted specification, there is a statistically significant difference between banks with different ex ante risk with low-risk banks increasing their equity ratios more than high-risk banks in response to the levies. However, the difference becomes statistically insignificant when we employ the matching strategy (Column 2) and introduce the full set of controls (Column 3).

\section{Table 7 around here}

The second set of results shows that the levies induced a larger compensating increase in portfolio risk for banks that were ex ante riskier. In the unweighted panel regression (Column 4), the estimated increase in the average risk weights is 0.045 for the median bank (consistent with the average effect presented in Table 3), but almost exactly zero for banks with a capital ratio 10 percentage points above the median (a capital ratio around $24 \%$ ) and almost twice as high for banks with a capital ratio 10 percentage points below the median (a capital ratio around 4\%). A similar pattern emerges in the specifications with regression weights (Column 5) and with the full set of controls (Column 6).

The third set of results documents that the combination of the two behavioral responses, the decrease in funding risk and the increase in portfolio risk, produces a significantly larger decrease in total risk for banks that were ex ante less risky in all three specifications. In the preferred specification (Column 9), the estimated change in the regulatory capital ratio is almost precisely zero for the median bank, but around 0.01 for banks with a capital ratio 10 percentage points above the median.

The results suggest that the behavioral responses induced by the bank levies differed systematically across banks with ex ante differences in total risk. While the decrease in funding risk was unrelated to the ex ante level of total risk, the increase in portfolio risk was much larger for riskier banks implying that the decrease in total risk was concentrated among relatively safe banks. 


\subsection{Stocks of assets and loans}

Finally, for policy purposes, it is important whether the levies on bank borrowing induced banks to reduce the size of their balance sheet; in particular, a contraction of lending can have adverse consequences for firms (Chodorow-Reich, 2014) and households (Jensen and Johannesen, 2017) in the real economy. To address this question, we estimate the usual set of models using as dependent variable the stock of assets (in logs) and a measure of retail lending - the stock of loans to firms and households (in logs). The results are reported in Table 8.

The first set of results strongly suggests that banks did not reduce the size of their balance sheets in response to the levies; in the preferred specification (Column 3), the point estimate on levy implies that levies were associated with an increase in total assets of around $1.5 \%$, but the effect is far from statistical significance. This finding indicates that the increase in the equity ratio, which is one of the key findings of the paper, is not driven by a reduction of the stock of assets.

Table 8 around here

The second set of results suggests that the bank levies may have fueled a sizable increase in lending; the coefficient on levy is insignificant in the two parsimonious specifications (Columns 4-5), but strongly positive when the full set of controls is included (Column 6). Taken at face value, the point estimate suggests that banks increased retail lending by around 8 percent in response to the levies. A possible interpretation is that the estimated increase in the average asset risk weights is driven by a portfolio shift into loans with relatively high risk weights from other asset categories with lower risk weights.

\section{Concluding remarks}

Levies on bank borrowing have become an important dimension of government intervention in financial markets. This paper has shown that the bank levies introduced by a number of European countries suffer from two fundamental weaknesses. First, the levies only penalize funding risk so the incentive to reduce total risk is eroded by the ability to substitute toward portfolio risk. Second, the incentive to shift risk to the asset side of 
the balance sheet is stronger for weakly capitalized banks, which are the banks that pose the greatest threat to financial stability.

Our analysis has several implications for policy design. First, the bank levies would be more effective in curbing bank risk if they penalized both funding risk and portfolio risk since this would reduce the scope for shifting of risk between the two sides of the balance sheet. Indeed, current reforms in the European Union aim to introduce bank levies in all member states where banks' levy payments are a function of their total borrowing as well as several other dimensions of risk. Second, the key innovation of the Basel III regulatory framework, the leverage ratio, which imposes a minimum ratio of regulatory capital to assets of $3 \%$, is likely to suffer from the same weakness as the bank levies. Since it constrains only funding risk, it is likely to induce substitution towards portfolio risk that could undermine the reduction in banks' total risk. This potential weakness has been widely discussed in policy circles, but advocates of the leverage ratio have appealed to a lack of empirical evidence on the shifting of risk within the balance sheet (e.g. Bank of England, 2014). The results presented in this paper reinforce the concern that such shifting may limit the value of the leverage ratio. There is also an important question over the appropriate measure of risk that should be used in Pigouvian taxation or in regulation. Acharya (2009) shows that regulatory mechanisms that are based only on a bank's own risk may fail to mitigate aggregate incentives for risk shifting and may even accentuate systemic risk. Acharya et al. (2016) develop a measure of a financial institution's contribution to systemic risk which directly addresses such macro-prudential considerations.

This discussion relates to broader questions about externalities in financial markets, the scope for corrective taxation and the interaction of such taxes with existing regulation. Stein (2013) argues that negative externalities in markets for securities financing transactions where distress and asset fire-sales by some borrowers may depress asset prices and tighten collateral constraints on other borrowers, creates a scope for Pigouvian taxes. Importantly, he points to complementarities in enforcement between existing regulation and new corrective taxes. Perotti and Suarez (2011) directly address the choice between bank regulation in the form of capital requirements and taxation in the form of taxes on short-term bank borrowing and show that the relative merits of the two corrective 
instruments depend on the precise nature of bank heterogeneity: regulation is more desirable when banks differ in their propensity to take gambles whereas taxation is more desirable when banks differ in their lending opportunities. In the presence of both types of heterogeneity, the optimal policy uses both taxation and regulation. Since Perotti and Suarez (2011) assume that regulation and taxation address exactly the same type of risky behavior, they do not find the same interaction between the two policy tools as in our model where regulation restricts total risk and bank levies fall only on funding risk. In general, regulation and taxation should both be expected to interact to create shifting between the two sides of the balance sheet as long as they target dimensions of risk that are not perfectly aligned.

\section{References}

[1] Acharya, V., 2009. A theory of systemic risk and design of prudential bank regulation, Journal of Financial Stability 5, 224-255.

[2] Acharya, V., Pedersen, L., Philippon, T., Richardson, M. 2016. Measuring Systemic Risk. Review of Financial Studies 30(1), 2-47.

[3] Admati A., Demarzo, P., Hellwig, M., Pfleiderer, P., 2010. Fallacies, Irrelevant Facts, and Myths in the Discussion of Capital Regulation: Why Bank Equity is Not Expensive, Stanford GSB Research Paper No. 2063

[4] Adrian, T., Shin, H., 2010. Liquidity and leverage. Journal of Financial Intermediation 19, 418-437

[5] Allen, F., Carletti, E., Marquez, R., 2011. Credit Market Competition and Capital Regulation. Review of Financial Studies 24(4), 983-1018.

[6] Bank of England, 2014, The Financial Policy Committee's review of the leverage ratio: A Consultation Paper, July 2014.

[7] Behn, M., Haselmann, R., Vig, V., 2016. The Limits of Model-based Regulation. ECB Working Paper No. 1928. 
[8] Buch, C.M., Hilberg, B., Tonzer, L., 2016. Taxing banks: an evaluation of the German bank levy. Journal of Banking and Finance 72, 52-66.

[9] Burman, L., Randolph, W., 1994. Measuring Permanent Responses to Capital-Gains Tax Changes in Panel Data. American Economic Review 84(4), p. 794-809.

[10] Capelle-Blancard, G., Havrylchyk, O., 2013. Incidence of Bank Levy and Bank Market Power. Review of Finance 21(3), 1023-1046.

[11] Célérier, C., Kick, T., Ongena, S., 2018. Taxing Bank Leverage: The Effects on Bank Capital Structure, Credit Supply and Risk-Taking. Working Paper

[12] Cheng, I-H, Hong H., Scheinkman, J.A., 2015, Yesterday's Heroes: Compensation and Risk at Financial Firms, Journal of Finance 63,1575-1608.

[13] Chodorow-Reich, G., 2014. The Employment Effects of Credit Market Disruptions: Firm-level Evidence from the 2008-09 Financial Crisis. Quarterly Journal of Economics 129(1), 1-59.

[14] De Haan, J.. Poghosyan, T. 2012. Bank size, market concentration, and bank earnings volatility in the US. Journal of International Financial Markets, Institutions and Money 22, 35-54.

[15] De Mooij, R., 2011. The Tax Elasticity of Corporate Debt: A Synthesis of Size and Variations. IMF Working Paper 11/95

[16] Devereux, M., 2014. New Bank Taxes: Why and What Will be the Effect? In: de Mooij, R., Nicodeme, G., (Eds), Taxation and Regulation of the Financial Sector, MIT Press

[17] Elfing, M., 2016. Arbitraging the Basel Securitization Framework: Evidence from German ABS Investment. Swiss Finance Institute Research Paper No. 14-65.

[18] Ellul, A., Yerramilli, V. 2013. Stronger Risk Controls, Lower Risk: Evidence from U.S. Bank Holding Companies. Journal of Finance 68, 1757-1803

[19] European Commission, 2012. Facts and figures on State aid in the EU Member States. Commission Staff Working Document, $\operatorname{COM}(2012) 778$ final 
[20] European Banking Authority, 2011. EBA Recommendation on the creation and supervisory oversight of temporary capital buffers to restore market confidence. 8 December 2011.

[21] Fullerton, D., Metcalf, G., 2002. Tax incidence, in: Auerbach, A. and Feldstein, M., (ed.), Handbook of Public Economics, 1787-1872

[22] Glasserman, P., Kang, W., 2014. Design of Risk Weights. Operations Research 62(6), 1204-1220.

[23] Haldane, A., 2013. Constraining discretion in bank regulation. Bank of England mimeo

[24] Hart, O., Zingales, L., 2011. A New Capital Regulation for Large Financial Institutions. American Law and Economics Review 13, 453-490.

[25] HM Treasury. Bank Levy - a consultation. July 2010.

[26] Houston, J.F., Lin, C., Lin, P., Ma, Y. 2010. Creditor rights, information sharing, and bank risk taking. Journal of Financial Economics 96, 485-512.

[27] International Monetary Fund, 2010. Financial Sector Taxation. The IMF's Report to the G-20 and Background Material.

[28] Iyer, R., Jensen, T., Johannesen, N., Sheridan, A., 2016. The Run for Safety: Financial Fragility and Deposit Insurance. Working paper.

[29] Jensen, T., Johannesen, N., 2017. The Consumption Effects of the 2007-2008 Financial Crisis: Evidence from Households in Denmark. American Economic Review, 107(11), 3386-3414

[30] Keen, M., de Mooij, R., 2016. Debt, Taxes and Banks. Journal of Money, Banking and Credit 48(1), p. 5-33.

[31] Kim, D., Santomero, A.M.,1988. Risk in Banking and Capital Regulation. Journal of Finance 43,1219-1233.

[32] King, M., 2009. The cost of equity for global banks: a CAPM perspective from 1990 to 2009. BIS Quarterly Review, p. 59-73. 
[33] Koehn, M., Santomero, A.M.,1980. Regulation of bank capital and portfolio risk. Journal of Finance 35,1235-1250.

[34] Kogler, M., 2016. On the Incidence of Bank Levies: Theory and Evidence. Working Paper.

[35] KPMG, 2011. Corporate and Indirect Tax Survey.

[36] KPMG, 2012. Bank Levies - comparison of certain jurisdictions. Edition IX.

[37] Kreicher, L., McCauley, R., McGuire, P., 2013. The 2011 FDIC Assessment on Banks' Managed Liabilities: Interest Rate and Balance-Sheet Responses, BIS Working Paper No. 413

[38] Laeven, L., Levine, R., 2009. Bank governance, regulation and risk taking. Journal of Financial Economics 93, 259-275.

[39] Laeven, L., Valencia, F., 2013. Resolution of Banking Crises: The Good, the Bad, and the Ugly. In Stijn Claessens, M. Ayhan Kose, Luc Laeven and Fabián Valencia (eds.), Financial Crises: Causes, Consequences, and Policy Responses, IMF.

[40] Lemmon, M., Roberts, M., Zender, J., 2008. Back to the Beginning: Persistence and the Cross-Section of Corporate Capital Structure. Journal of Finance 63,1575-1608.

[41] Mariathasan, M., Merrouche, O., 2014. The manipulation of basel risk-weights. Journal of Financial Intermediation 23(3), 300-321.

[42] Pathan, S., 2009. Strong boards, CEO power and bank risk-taking. Journal of Banking and Finance 33, 1340-1350.

[43] Perotti, E., Suarez, J., 2011. A pigouvian approach to liquidity regulation. CEPR Discussion Paper No. 8271

[44] Rime, B., 2001. Capital Requirements and Bank Behaviour: Empirical Evidence for Switzerland. Journal of Banking and Finance 25, 789-805.

[45] Rochet, J., 1992. Capital Requirements and the Behavior of Commercial Banks. European Economic Review 36, 1137-1178. 
[46] Santos, J., 2011. Bank Corporate Loan Pricing Following the Subprime Crisis. Review of Financial Studies 24(6), 1916-1943.

[47] Sargan, J., 1958. The Estimation of Economic Relationships using Instrumental Variables. Econometrica 26(3), p. 393-415.

[48] Schepens, G., 2016. Taxes and Bank Capital Structure. Journal of Financial Economics $120(3)$, p. 585-600.

[49] Shin, H.S., 2009. Reflections on Northern Rock: The Bank Run That Heralded the Global Financial Crisis. Journal of Economic Perspectives 23(1), 101-120.

[50] Stein, J., 2013. The Fire-Sales Problem and Securities Financing Transactions. Speech, November 7

[51] Yagan, D., 2015. Capital Tax Reform and the Real Economy: The Effects of the 2003 Dividend Tax Cut. American Economic Review 105(12), p. 3531-3563. 


\begin{tabular}{|c|c|c|c|}
\hline & Base & Rate structure in 2012 & Entry into force \\
\hline \multicolumn{4}{|c|}{ LEVIES ON BANK BORROWING: } \\
\hline Austria* & $\begin{array}{l}\text { total liabilities net of equity } \\
\text { and insured deposits }\end{array}$ & $\begin{array}{l}0.000 \% \text { up to } € 1 \text { billion } \\
0.055 \% \text { up to } € 20 \text { billion } \\
0.085 \% \text { above } € 20 \text { billion }\end{array}$ & 2011 \\
\hline Belgium & $\begin{array}{l}\text { total liabilities net of equity } \\
\text { and insured deposits }\end{array}$ & $0.035 \%$ & 2012 \\
\hline Cyprus & total liabilities net of equity & $0.090 \%$ & 2011 \\
\hline Germany & $\begin{array}{l}\text { total liabilities net of equity } \\
\text { and insured deposits }\end{array}$ & $\begin{array}{l}0.000 \% \text { up to } € 300 \text { million } \\
0.020 \% \text { up to } € 10 \text { billion } \\
0.030 \% \text { up to } € 100 \text { billion } \\
0.040 \% \text { up to } € 200 \text { billion } \\
0.050 \% \text { up to } € 300 \text { billion } \\
0.060 \% \text { above } € 300 \text { billion }\end{array}$ & 2011 \\
\hline Latvia & $\begin{array}{l}\text { total liabilities net of equity } \\
\text { and insured deposits }\end{array}$ & $0.036 \%$ & 2011 \\
\hline Portugal & $\begin{array}{l}\text { total liabilities net of equity } \\
\text { and subordinated debt }\end{array}$ & $0.050 \%$ & 2011 \\
\hline Romania & $\begin{array}{l}\text { total liabilities net of equity } \\
\text { and insured deposits }\end{array}$ & $0.100 \%$ & 2011 \\
\hline Slovakia & $\begin{array}{l}\text { total liabilities net of equity } \\
\text { and insured deposits }\end{array}$ & $0.400 \%$ & 2012 \\
\hline Sweden & $\begin{array}{l}\text { total liabilities net of equity } \\
\text { and insured deposits }\end{array}$ & $0.036 \%$ & 2009 \\
\hline Netherlands & $\begin{array}{l}\text { total liabilities net of equity } \\
\text { and insured deposits }\end{array}$ & $\begin{array}{l}0.000 \% \text { up to } € 20 \text { billion } \\
0,044 \% \text { above } € 20 \text { billion } \\
\text { (half rate for long-term funding) }\end{array}$ & 2012 \\
\hline UK & $\begin{array}{l}\text { total liabilities net of equity } \\
\text { and insured deposits but } \\
\text { netting of gross assets and } \\
\text { liabilities against the same } \\
\text { counterpart and deduction for }\end{array}$ & $\begin{array}{l}0.000 \% \text { up to } £ 20 \text { billion } \\
0.088 \% \text { above } £ 20 \text { billion } \\
\text { (half rate for long-term funding) }\end{array}$ & 2011 \\
\hline \multicolumn{4}{|c|}{ OTHER LEVIES: } \\
\hline France & $\begin{array}{l}\text { minimal amount of own funds } \\
\text { required to comply with } \\
\text { coverage ratio }\end{array}$ & $0.250 \%$ & 2011 \\
\hline Hungary & $\begin{array}{l}\text { total assets net of interbank } \\
\text { loans }\end{array}$ & $\begin{array}{l}0.150 \% \text { up to HUF } 50 \text { billion } \\
0.530 \% \text { above HUF } 50 \text { billion }\end{array}$ & 2010 \\
\hline Slovenia** & Total assets & $0.100 \%$ & 2011 \\
\hline
\end{tabular}

Notes: * Levy payments in 2011-2013 were a function of the balance sheet in 2010; ${ }^{* *}$ Exceptions apply depending on the stock and growth of lending to non-banks 


\begin{tabular}{|c|c|c|c|c|c|c|c|c|c|c|c|}
\hline & $\overline{(1)}$ & (2) & (3) & (4) & (5) & (6) & $\overline{(7)}$ & (8) & $\overline{(9)}$ & (10) & (11) \\
\hline & \multicolumn{3}{|c|}{ All banks } & \multicolumn{2}{|c|}{ Levy } & \multicolumn{2}{|c|}{ Non-levy } & \multicolumn{2}{|c|}{ High capital } & \multicolumn{2}{|c|}{ Low capital } \\
\hline & Obs & Mean & S.d. & Mean & S.d. & Mean & S.d. & Mean & S.d. & Mean & S.d. \\
\hline \multicolumn{12}{|c|}{ Panel A: Balance sheet totals (euro millions) } \\
\hline Total assets & 13,658 & 24,391 & 134,452 & 35,581 & 179,954 & 13,676 & 64,392 & 3,864 & 27,175 & 45,713 & 189,559 \\
\hline Retail loans & 13,658 & 11,980 & 58,786 & 15,915 & 74,383 & 8,211 & 37,927 & 1,694 & 10,971 & 22,526 & 82,291 \\
\hline \multicolumn{12}{|c|}{ Panel B: Balance sheet structure (share of balance sheet total) } \\
\hline Customer deposits & 13,658 & $57.6 \%$ & $23.2 \%$ & $66.6 \%$ & $22.1 \%$ & $49.0 \%$ & $21.0 \%$ & $61.0 \%$ & $22.9 \%$ & $53.2 \%$ & $22.6 \%$ \\
\hline Deposits from banks & 13,658 & $9.9 \%$ & $15.2 \%$ & $11.0 \%$ & $13.2 \%$ & $8.9 \%$ & $16.8 \%$ & $7.8 \%$ & $13.5 \%$ & $10.6 \%$ & $15.8 \%$ \\
\hline Other liabilities & 13,658 & $22.9 \%$ & $21.5 \%$ & $14.5 \%$ & $20.0 \%$ & $30.9 \%$ & $19.8 \%$ & $19.2 \%$ & $19.2 \%$ & $28.8 \%$ & $22.3 \%$ \\
\hline Equity & 13,658 & $9.5 \%$ & $6.2 \%$ & $7.9 \%$ & $5.0 \%$ & $11.0 \%$ & $6.8 \%$ & $11.8 \%$ & $7.4 \%$ & $7.4 \%$ & $3.2 \%$ \\
\hline Loans to retail customers & 13,658 & $59.5 \%$ & $19.4 \%$ & $55.6 \%$ & $17.8 \%$ & $63.3 \%$ & $20.1 \%$ & $55.1 \%$ & $19.7 \%$ & $64.2 \%$ & $17.6 \%$ \\
\hline Loans to banks & 13,658 & $9.0 \%$ & $13.2 \%$ & $10.1 \%$ & $13.0 \%$ & $7.9 \%$ & $13.3 \%$ & $10.3 \%$ & $15.3 \%$ & $7.0 \%$ & $10.0 \%$ \\
\hline Securities & 13,658 & $20.5 \%$ & $13.9 \%$ & $23.0 \%$ & $14.0 \%$ & $18.2 \%$ & $13.5 \%$ & $23.1 \%$ & $14.5 \%$ & $17.8 \%$ & $12.2 \%$ \\
\hline Other assets & 13,658 & $10.9 \%$ & $12.1 \%$ & $11.3 \%$ & $12.9 \%$ & $10.6 \%$ & $11.4 \%$ & $11.4 \%$ & $13.4 \%$ & $11.1 \%$ & $11.0 \%$ \\
\hline \multicolumn{12}{|l|}{ Panel C: Profitability measures } \\
\hline Return on assets (profits / assets) & 13,652 & $0.6 \%$ & $0.8 \%$ & $0.6 \%$ & $0.6 \%$ & $0.7 \%$ & $0.9 \%$ & $0.8 \%$ & $0.8 \%$ & $0.6 \%$ & $0.7 \%$ \\
\hline Return on equity (profits / equity) & 13,651 & $5.0 \%$ & $6.1 \%$ & $4.8 \%$ & $5.4 \%$ & $5.3 \%$ & $6.7 \%$ & $4.8 \%$ & $5.5 \%$ & $5.4 \%$ & $6.6 \%$ \\
\hline \multicolumn{12}{|l|}{ Panel D: Risk measures } \\
\hline Regulatory capital ratio & 13,658 & $16.4 \%$ & $5.7 \%$ & $16.5 \%$ & $5.1 \%$ & $16.4 \%$ & $6.2 \%$ & $20.3 \%$ & $5.5 \%$ & $13.0 \%$ & $3.0 \%$ \\
\hline Average risk weight & 13,658 & $64.1 \%$ & $19.9 \%$ & $58.6 \%$ & $17.8 \%$ & $69.4 \%$ & $20.4 \%$ & $62.0 \%$ & $19.6 \%$ & $67.1 \%$ & $19.9 \%$ \\
\hline Impaired loan ratio (change) & 11,582 & $0.5 \%$ & $0.8 \%$ & $0.4 \%$ & $0.7 \%$ & $0.6 \%$ & $0.8 \%$ & $0.4 \%$ & $0.8 \%$ & $0.5 \%$ & $0.8 \%$ \\
\hline Distance to return on equity & 13,651 & $3.7 \%$ & $5.9 \%$ & $3.2 \%$ & $5.3 \%$ & $4.3 \%$ & $6.3 \%$ & $3.1 \%$ & $5.2 \%$ & $4.0 \%$ & $6.1 \%$ \\
\hline Distance to return on trading assets & 3,870 & $6.1 \%$ & $23.1 \%$ & $13.7 \%$ & $44.1 \%$ & $4.3 \%$ & $13.2 \%$ & $6.4 \%$ & $32.2 \%$ & $5.3 \%$ & $14.7 \%$ \\
\hline Standard deviation of daily returns & 568 & $2.9 \%$ & $1.6 \%$ & $3.2 \%$ & $1.7 \%$ & $2.8 \%$ & $1.6 \%$ & $2.9 \%$ & $1.7 \%$ & $2.9 \%$ & $1.6 \%$ \\
\hline \multicolumn{12}{|l|}{ Panel E: Macro controls } \\
\hline Inflation & 13,658 & $2.3 \%$ & $1.3 \%$ & $2.1 \%$ & $1.3 \%$ & $2.4 \%$ & $1.2 \%$ & $2.2 \%$ & $1.2 \%$ & $2.3 \%$ & $1.4 \%$ \\
\hline GDP growth & 13,658 & $0.6 \%$ & $3.0 \%$ & $1.3 \%$ & $2.9 \%$ & $0.1 \%$ & $3.0 \%$ & $0.6 \%$ & $2.9 \%$ & $0.6 \%$ & $3.1 \%$ \\
\hline Corporate tax rate & 13,645 & $29.0 \%$ & $5.4 \%$ & $30.5 \%$ & $5.6 \%$ & $27.6 \%$ & $4.6 \%$ & $29.7 \%$ & $5.2 \%$ & $28.8 \%$ & $5.6 \%$ \\
\hline
\end{tabular}

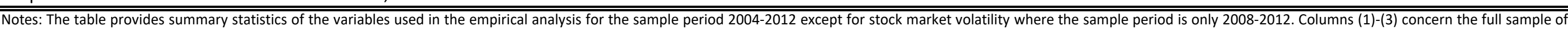

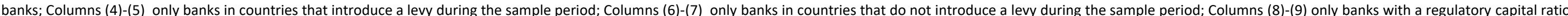

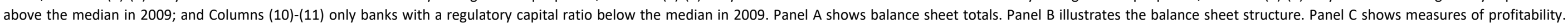

Panel $D$ shows various measures of risk. Panel E shows control variables at the country-level. 
Table 3: Baseline results

\begin{tabular}{|c|c|c|c|c|c|c|}
\hline & (1) & $\overline{(2)}$ & (3) & (4) & (5) & (6) \\
\hline & \multicolumn{2}{|c|}{ Equity / Assets } & \multicolumn{2}{|c|}{ RWA / Assets } & \multicolumn{2}{|c|}{ Capital / RWA } \\
\hline & no weight & weight & no weight & weight & no weight & weight \\
\hline Levy & $\begin{array}{c}0.0129 * * * \\
(0.0019)\end{array}$ & $\begin{array}{c}0.0087^{* * *} \\
(0.0019)\end{array}$ & $\begin{array}{c}0.0390 * * * \\
(0.0095)\end{array}$ & $\begin{array}{c}0.0274 * * * \\
(0.0089)\end{array}$ & $\begin{array}{c}0.0091 * * * \\
(0.0021)\end{array}$ & $\begin{array}{c}0.0062 * * \\
(0.0026)\end{array}$ \\
\hline Assets (logs) & $\begin{array}{c}-0.1232 * * * \\
(0.0199)\end{array}$ & $\begin{array}{c}-0.1160 * * * \\
(0.0172)\end{array}$ & $\begin{array}{l}-0.0214 \\
(0.0341)\end{array}$ & $\begin{array}{l}-0.0725^{*} \\
(0.0415)\end{array}$ & $\begin{array}{c}-0.0568^{* * *} \\
(0.0097)\end{array}$ & $\begin{array}{c}-0.0563^{* * *} \\
(0.0112)\end{array}$ \\
\hline Assets squared (logs) & $\begin{array}{c}0.0052^{* * *} \\
(0.0011)\end{array}$ & $\begin{array}{c}0.0048 * * * \\
(0.0009)\end{array}$ & $\begin{array}{c}-0.0081 * * * \\
(0.0021)\end{array}$ & $\begin{array}{c}-0.0058^{* *} \\
(0.0026)\end{array}$ & $\begin{array}{c}0.0021^{* * *} \\
(0.0006)\end{array}$ & $\begin{array}{c}0.0019 * * * \\
(0.0007)\end{array}$ \\
\hline Profitability & $\begin{array}{c}0.5435^{* * *} \\
(0.0747)\end{array}$ & $\begin{array}{c}0.5820 * * * \\
(0.0918)\end{array}$ & $\begin{array}{c}0.4980 \\
(0.3650)\end{array}$ & $\begin{array}{c}0.1344 \\
(0.4356)\end{array}$ & $\begin{array}{c}0.2668 * * * \\
(0.0879)\end{array}$ & $\begin{array}{c}0.3477^{* * *} \\
(0.1222)\end{array}$ \\
\hline Inflation & $\begin{array}{l}-0.0012^{*} \\
(0.0007)\end{array}$ & $\begin{array}{l}-0.0009 \\
(0.0007)\end{array}$ & $\begin{array}{l}-0.0013 \\
(0.0020)\end{array}$ & $\begin{array}{l}-0.0011 \\
(0.0021)\end{array}$ & $\begin{array}{l}-0.0002 \\
(0.0006)\end{array}$ & $\begin{array}{l}-0.0004 \\
(0.0007)\end{array}$ \\
\hline GDP growth rate & $\begin{array}{c}-0.0008 * * \\
(0.0003)\end{array}$ & $\begin{array}{l}-0.0004 \\
(0.0004)\end{array}$ & $\begin{array}{c}0.0014 \\
(0.0012)\end{array}$ & $\begin{array}{c}0.0023^{* *} \\
(0.0011)\end{array}$ & $\begin{array}{l}-0.0004 \\
(0.0003)\end{array}$ & $\begin{array}{l}-0.0002 \\
(0.0004)\end{array}$ \\
\hline Corporate tax rate & $\begin{array}{l}-0.0183 \\
(0.0319)\end{array}$ & $\begin{array}{l}-0.0109 \\
(0.0317)\end{array}$ & $\begin{array}{c}0.1380 \\
(0.1897)\end{array}$ & $\begin{array}{l}0.3026^{*} \\
(0.1770)\end{array}$ & $\begin{array}{c}0.0081 \\
(0.0453)\end{array}$ & $\begin{array}{c}0.0300 \\
(0.0482)\end{array}$ \\
\hline Observations & 12,680 & 12,431 & 12,680 & 12,431 & 12,680 & 12,431 \\
\hline R-squared & 0.9282 & 0.9368 & 0.8696 & 0.8813 & 0.8701 & 0.8605 \\
\hline bank FE & YES & YES & YES & YES & YES & YES \\
\hline time FE & YES & YES & YES & YES & YES & YES \\
\hline
\end{tabular}

Note: The dependent variable is the ratio of book equity to assets in columns (1)-(2); the ratio of risk-weighted assets to assets in columns (3)-(4); and the ratio of regulatory capital to risk-weighted assets in columns (5)-(6); the regressions are unweighted in columns (1), (3) and (5) and weighted in order to match banks with similar pre-levy trends in columns (2), (4) and (6); levy is a dummy variable at the country-year level taking the value one when there is a bank levy in place; log assets is the log of total assets; log assets squared is the log of assets squared; profitability is the ratio of pre-tax profits to assets; inflation is the rate of inflation at the country-year level; gdp growth is the rate of GDP growth at the country-year level; corporate tax rate is the corporate tax rate at the country-year level. All three outcome variables as well as profitability are winsorized at the 5/95 level. Standard errors are clustered at the country-year level and at the bank level; ${ }^{* * *},{ }^{* *}$ and ${ }^{*}$ indicate statistical significance at the $1 \%, 5 \%$ and $10 \%$ level respectively. 


\begin{tabular}{|c|c|c|c|c|c|c|c|c|}
\hline & $\begin{array}{c}\text { (1) } \\
\text { no weight }\end{array}$ & $\begin{array}{c}\text { (2) } \\
\text { no weight }\end{array}$ & $\begin{array}{c}\text { (3) } \\
\text { no weight }\end{array}$ & $\begin{array}{c}\text { (4) } \\
\text { no weight }\end{array}$ & $\begin{array}{c}\text { (5) } \\
\text { no weight }\end{array}$ & $\begin{array}{c}\text { (6) } \\
\text { no weight }\end{array}$ & $\begin{array}{c}\text { (7) } \\
\text { no weight }\end{array}$ & $\begin{array}{c}(8) \\
\text { weight }\end{array}$ \\
\hline PANEL A & \multicolumn{8}{|c|}{ Equity / Assets } \\
\hline Levy & $\begin{array}{c}0.0129 * * * \\
(0.0019)\end{array}$ & $\begin{array}{c}0.0138^{* * *} \\
(0.0020)\end{array}$ & $\begin{array}{c}0.0137 * * * \\
(0.0021)\end{array}$ & $\begin{array}{c}0.0057^{* * *} \\
(0.0019)\end{array}$ & $\begin{array}{c}0.0120 * * * \\
(0.0018)\end{array}$ & $\begin{array}{c}0.0136^{* * *} \\
(0.0020)\end{array}$ & $\begin{array}{c}0.0076^{* * *} \\
(0.0023)\end{array}$ & $\begin{array}{c}0.0044^{* *} \\
(0.0022)\end{array}$ \\
\hline Observations & 12,680 & 11,099 & 11,099 & 12,680 & 12,680 & 12,597 & 11,099 & 10,936 \\
\hline R-squared & 0.9282 & 0.9259 & 0.9256 & 0.9307 & 0.9325 & 0.9272 & 0.9319 & 0.9391 \\
\hline PANEL B & \multicolumn{8}{|c|}{ RWA /Assets } \\
\hline Levy & $\begin{array}{c}0.0390 * * * \\
(0.0095)\end{array}$ & $\begin{array}{c}0.0418^{* * *} \\
(0.0096)\end{array}$ & $\begin{array}{c}0.0413^{* * *} \\
(0.0096)\end{array}$ & $\begin{array}{c}0.0344 * * * \\
(0.0091)\end{array}$ & $\begin{array}{c}0.0184^{* *} \\
(0.0081)\end{array}$ & $\begin{array}{c}0.0392^{* * *} \\
(0.0100)\end{array}$ & $\begin{array}{c}0.0269 * * * \\
(0.0072)\end{array}$ & $\begin{array}{c}0.0235^{* * *} \\
(0.0065)\end{array}$ \\
\hline Observations & 12,680 & 11,099 & 11,099 & 12,680 & 12,680 & 12,597 & 11,099 & 10,936 \\
\hline R-squared & 0.8696 & 0.8702 & 0.8697 & 0.8734 & 0.8741 & 0.8701 & 0.8811 & 0.8945 \\
\hline PANEL C & \multicolumn{8}{|c|}{ Capital / RWA } \\
\hline Levy & $\begin{array}{c}0.0091 * * * \\
(0.0021)\end{array}$ & $\begin{array}{c}0.0087^{* * *} \\
(0.0024)\end{array}$ & $\begin{array}{c}0.0089 * * * \\
(0.0025)\end{array}$ & $\begin{array}{c}0.0008 \\
(0.0026)\end{array}$ & $\begin{array}{c}0.0064^{* * *} \\
(0.0018)\end{array}$ & $\begin{array}{c}0.0089 * * * \\
(0.0021)\end{array}$ & $\begin{array}{c}0.0006 \\
(0.0024)\end{array}$ & $\begin{array}{l}-0.0008 \\
(0.0022)\end{array}$ \\
\hline Observations & 12,680 & 11,099 & 11,099 & 12,680 & 12,680 & 12,597 & 11,099 & 10,936 \\
\hline R-squared & 0.8701 & 0.8716 & 0.8717 & 0.8747 & 0.8753 & 0.8703 & 0.8826 & 0.8763 \\
\hline bank FE & YES & YES & YES & YES & YES & YES & YES & YES \\
\hline time FE & YES & YES & YES & YES & YES & YES & YES & YES \\
\hline time $\mathrm{FE} \times$ size & NO & YES & NO & NO & NO & NO & YES & YES \\
\hline time FE $\times$ capital & NO & NO & YES & NO & NO & NO & YES & YES \\
\hline time $\mathrm{FE} \times$ region & NO & NO & NO & YES & NO & NO & YES & YES \\
\hline country $\times$ time & NO & NO & NO & NO & YES & NO & YES & YES \\
\hline regulatory & NO & NO & NO & NO & NO & YES & YES & YES \\
\hline
\end{tabular}

Note: The dependent variable is the ratio of book equity to assets in Panel A; the ratio of risk-weighted assets to assets in Panel B; and the ratio of regulatory capital to risk-weighted assets in Panel C. The regressions are unweighted in columns (1)-(7) and weighted in order to match banks with similar pre-levy trends in column (8); levy is a dummy variable at the country-year level taking the value one when there is a bank levy in place; size is a set of dummies indicating the quintiles in the distribution of total assets in 2008; capital is a set of dummies indicating the quintiles in the distribution of the regulatory capital ratio in 2008; region is a set of dummies indicating four geographical regions; country is a set of dummies indicating the country; regulatory is a set of variables capturing other government interventions in the banking industry than the bank levies. All regressions include the following set of controls: log of total assets, log of assets squared, ratio of pre-tax profits to assets, inflation, gdp growth and corporate tax rate. The three outcome variables are winsorized at the $5 / 95$ level. Standard errors are clustered at the country-year level and at the bank level; ***,** and * indicate statistical significance at the $1 \%, 5 \%$ and $10 \%$ level respectively. 


\begin{tabular}{|c|c|c|c|c|c|c|}
\hline & $\begin{array}{c}\text { (1) } \\
\text { no weight } \\
\text { OLS }\end{array}$ & $\begin{array}{c}\text { (2) } \\
\text { weight } \\
\text { OLS }\end{array}$ & $\begin{array}{c}\text { (3) } \\
\text { weight } \\
\text { OLS }\end{array}$ & $\begin{array}{c}\text { (4) } \\
\text { no weight } \\
\text { IV }\end{array}$ & $\begin{array}{c}\text { (5) } \\
\text { weight } \\
\text { IV }\end{array}$ & $\begin{array}{c}(6) \\
\text { weight } \\
\text { IV }\end{array}$ \\
\hline PANEL A & \multicolumn{6}{|c|}{ Equity / Assets } \\
\hline Top levy rate & $\begin{array}{c}0.2012 * * * \\
(0.0363)\end{array}$ & $\begin{array}{c}0.1358^{* * *} \\
(0.0352)\end{array}$ & $\begin{array}{c}0.0795^{* *} \\
(0.0358)\end{array}$ & & & \\
\hline Marginal levy rate & & & & $\begin{array}{c}0.4689 * * * \\
(0.0525)\end{array}$ & $\begin{array}{c}0.3138^{* * *} \\
(0.0514)\end{array}$ & $\begin{array}{l}0.1387^{*} \\
(0.0716)\end{array}$ \\
\hline Observations & 12,618 & 12,369 & 10,878 & 12,618 & 12,369 & 10,878 \\
\hline R-squared & 0.9260 & 0.9343 & 0.9360 & 0.3373 & 0.3131 & 0.3761 \\
\hline PANEL B & \multicolumn{6}{|c|}{ RWA /Assets } \\
\hline Top levy rate & $\begin{array}{c}0.5992^{* * *} \\
(0.1508)\end{array}$ & $\begin{array}{c}0.4216^{* * *} \\
(0.1429)\end{array}$ & $\begin{array}{c}0.3317^{* * *} \\
(0.1202)\end{array}$ & & & \\
\hline Marginal levy rate & & & & $\begin{array}{c}1.3963^{* * *} \\
(0.1921)\end{array}$ & $\begin{array}{c}0.9739 * * * \\
(0.2106)\end{array}$ & $\begin{array}{c}0.5789 * * \\
(0.2323)\end{array}$ \\
\hline Observations & 12,618 & 12,369 & 10,878 & 12,618 & 12,369 & 10,878 \\
\hline R-squared & 0.8706 & 0.8824 & 0.8947 & 0.4111 & 0.4120 & 0.5172 \\
\hline PANEL C & \multicolumn{6}{|c|}{ Capital / RWA } \\
\hline Top levy rate & $\begin{array}{c}0.1412^{* * *} \\
(0.0360)\end{array}$ & $\begin{array}{c}0.0974 * * \\
(0.0418)\end{array}$ & $\begin{array}{l}-0.0042 \\
(0.0385)\end{array}$ & & & \\
\hline Marginal levy rate & & & & $\begin{array}{c}0.3291^{* * *} \\
(0.0621)\end{array}$ & $\begin{array}{c}0.2251^{* * *} \\
(0.0753)\end{array}$ & $\begin{array}{c}-0.0074 \\
(0.0805)\end{array}$ \\
\hline Observations & 12,618 & 12,369 & 10,878 & 12,618 & 12,369 & 10,878 \\
\hline R-squared & 0.8691 & 0.8592 & 0.8748 & 0.1553 & 0.1850 & 0.2898 \\
\hline bank FE & YES & YES & YES & YES & YES & YES \\
\hline time FE & YES & YES & YES & YES & YES & YES \\
\hline time FE $\times$ size & NO & NO & YES & NO & NO & YES \\
\hline time FE $\times$ capital & NO & NO & YES & NO & NO & YES \\
\hline time $\mathrm{FE} \times$ region & NO & NO & YES & NO & NO & YES \\
\hline country $\times$ time & NO & NO & YES & NO & NO & YES \\
\hline regulatory & NO & NO & YES & NO & NO & YES \\
\hline
\end{tabular}

Note: The dependent variable is the ratio of book equity to assets in Panel A; the ratio of risk-weighted assets to assets in Panel $\mathrm{B}$; and the ratio of regulatory capital to risk-weighted assets in Panel C. The regressions are unweighted in columns (1) and (4) and weighted in order to match banks with similar pre-levy trends in columns (2)-(3) and (5)-(6); top levy rate is the highest marginal levy rate at the country-year level; marginal levy rate is the estimated marginal levy rate at the bank-year level; size is a set of dummies indicating the quintiles in the distribution of total assets in 2008; capital is a set of dummies indicating the quintiles in the distribution of the regulatory capital ratio in 2008; region is a set of dummies indicating four geographical regions; country is a set of dummies indicating the country; regulatory is a set of variables capturing other government interventions in the banking industry than the bank levies. All regressions include the following set of controls: log of total assets, log of assets squared, ratio of pre-tax profits to assets, inflation, gdp growth and corporate tax rate. In columns (4)-(6), the marginal levy rate is instrumented with the top marginal levy rate. All three outcomes are winsorized at the 5/95 level. Slovakian banks face extremely high levy rates and are therefore omitted from the sample. Standard errors are clustered at the country-year level and at the bank level in columns (1)-(3) and at the bank-level in columns (4)-(6); ${ }^{* * *},{ }^{* *}$ and ${ }^{*}$ indicate statistical significance at the $1 \%$, $5 \%$ and $10 \%$ level respectively. 


\begin{tabular}{|c|c|c|c|c|c|c|}
\hline & $\begin{array}{c}(1) \\
\text { no weight }\end{array}$ & $\begin{array}{c}(2) \\
\text { weight }\end{array}$ & $\begin{array}{c}(3) \\
\text { weight }\end{array}$ & $\begin{array}{c}\text { (4) } \\
\text { no weight }\end{array}$ & $\begin{array}{c}\text { (5) } \\
\text { weight }\end{array}$ & $\begin{array}{c}6) \\
\text { weight }\end{array}$ \\
\hline \multicolumn{7}{|c|}{ Panel A: total risk } \\
\hline & \multicolumn{3}{|c|}{ Volatility of market return } & \multicolumn{3}{|c|}{ Distance to reference book return to equity } \\
\hline Levy & $\begin{array}{c}-1.0061^{* * *} \\
(0.2971)\end{array}$ & $\begin{array}{c}-0.7406^{* *} \\
(0.2840)\end{array}$ & $\begin{array}{c}-0.7541^{* *} \\
(0.2913)\end{array}$ & $\begin{array}{c}0.0031 \\
(0.0035)\end{array}$ & $\begin{array}{c}0.0039 \\
(0.0041)\end{array}$ & $\begin{array}{c}0.0060 \\
(0.0060)\end{array}$ \\
\hline Observations & 447 & 439 & 408 & 12,679 & 12,430 & 10,935 \\
\hline R-squared & 0.7339 & 0.7437 & 0.7890 & 0.5539 & 0.5440 & 0.5286 \\
\hline
\end{tabular}

Panel B: portfolio risk

\begin{tabular}{lcccccc} 
& \multicolumn{3}{c}{ Distance to reference return to trading assets } & \multicolumn{3}{c}{ Impaired loans } \\
Levy & 0.0146 & 0.0133 & $0.0341^{* *}$ & $0.0053^{* * *}$ & $0.0054^{* * *}$ & $0.0014^{*}$ \\
& $(0.0125)$ & $(0.0133)$ & $(0.0147)$ & $(0.0015)$ & $(0.0013)$ & $(0.0007)$ \\
& & & & & & \\
Observations & 3,705 & 3,614 & 3,493 & 10,958 & 10,779 & 9,443 \\
R-squared & 0.5793 & 0.5724 & 0.5882 & 0.5094 & 0.4856 & 0.6011
\end{tabular}

\begin{tabular}{|c|c|c|c|c|c|c|}
\hline bank FE & YES & YES & YES & YES & YES & YES \\
\hline time FE & YES & YES & YES & YES & YES & YES \\
\hline time FE $\times$ size & NO & NO & YES & NO & NO & YES \\
\hline time FE $\times$ capital & NO & NO & YES & NO & NO & YES \\
\hline time $\mathrm{FE} \times$ region & NO & NO & YES & NO & NO & YES \\
\hline regulatory & NO & NO & YES & NO & NO & YES \\
\hline
\end{tabular}

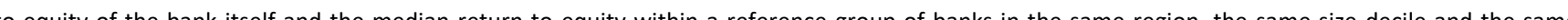
to equily of he baki equity-ratio decile as the bank itself (colums (4)-(6) of Panel $A$ ), the absolute diference between the return to secutirtes and derivalives of the bank itself and the medlan return to secutres and dervatives win ratio decile as the bank itself (collums (1)-(3) of Panel B), the change in the impared loans relatve to gross loans (colums (4)-(6) of Panel B). The regressions are unweighted in columns (1) and (4) and weighted in order to match banks with similar pre-levy trends in columns (2)-(3) and (5)-(6); levy is a dummy variable at the country-year level taking the value one when there is a bank levy in place; size is a set of dummies indicating the quintiles in the distribution of total assets in 2008; capital is a set of dummies indicating the quintiles in the distribution of the regulatory capital ratio in 2008; region a set of dummies indicating four geographical regions; country is a set of dummies indicating the country; regulatory is a set of variables capturing other government interventions in the banking industry than the bank levies. All regressions include the following set of controls: log of total assets, log of assets squared, ratio of pre-tax profits to assets, inflation, gdp growth and corporate tax rate. All outcomes are winsorized at the 5/95 level. Standard errors are clustered at the country-year level and at the bank level; ${ }^{* * *},{ }^{* *}$ and ${ }^{*}$ indicate statistical significance at the $1 \%, 5 \%$ and $10 \%$ level respectively. 


\begin{tabular}{|c|c|c|c|c|c|c|c|c|c|}
\hline \multirow[b]{3}{*}{ VARIABLES } & (1) & & (3) & (4) & (5) & (6) & (7) & (8) & (9) \\
\hline & \multicolumn{3}{|c|}{ Equity / Assets } & \multicolumn{3}{|c|}{ Risk weighted assets /Assets } & \multicolumn{3}{|c|}{ Capital / Risk weighted assets } \\
\hline & no weight & weight & weight & no weight & weight & weight & no weight & weight & weight \\
\hline \multirow[t]{2}{*}{ Levy } & $0.0129 * * *$ & $0.0087^{* * *}$ & $0.0043 * *$ & $0.0450 * * *$ & $0.0304 * * *$ & $0.0258 * * *$ & $0.0078^{* * *}$ & $0.0058^{* * *}$ & -0.0014 \\
\hline & $(0.0017)$ & $(0.0017)$ & (0.0019) & $(0.0100)$ & $(0.0101)$ & $(0.0070)$ & $(0.0021)$ & $(0.0022)$ & $(0.0022)$ \\
\hline \multirow[t]{2}{*}{ Levy $\times$ Capital ratio (in 2008) } & 0.0007 & 0.0003 & 0.0002 & $-0.0043 * * *$ & $-0.0031^{*}$ & $-0.0045^{* * *}$ & $0.0012^{* *}$ & $0.0013^{* *}$ & $0.0011 * *$ \\
\hline & $(0.0004)$ & $(0.0004)$ & $(0.0004)$ & $(0.0015)$ & $(0.0018)$ & $(0.0013)$ & $(0.0005)$ & $(0.0006)$ & $(0.0005)$ \\
\hline Observations & 11,463 & 11,294 & 10,936 & 11,463 & 11,294 & 10,936 & 11,463 & 11,294 & 10,936 \\
\hline R-squared & 0.9260 & 0.9327 & 0.9392 & 0.8712 & 0.8810 & 0.8949 & 0.8721 & 0.8649 & 0.8773 \\
\hline bank FE & YES & YES & YES & YES & YES & YES & YES & YES & YES \\
\hline time FE & YES & YES & YES & YES & YES & YES & YES & YES & YES \\
\hline time $\mathrm{FE} \times$ size & NO & NO & YES & NO & NO & YES & NO & NO & YES \\
\hline time FE $\times$ capital & NO & NO & YES & NO & NO & YES & NO & NO & YES \\
\hline time $\mathrm{FE} \times$ region & NO & NO & YES & NO & NO & YES & NO & NO & YES \\
\hline country $\times$ time & NO & NO & YES & NO & NO & YES & NO & NO & YES \\
\hline regulatory & NO & NO & YES & NO & NO & YES & NO & NO & YES \\
\hline
\end{tabular}

Note: The dependent variable is the ratio of book equity to assets in columns (1)-(3); the ratio of risk-weighted assets to assets in columns (4)-(6); and the ratio of regulatory capital to risk-weighted assets in columns (7)-(9); the regressions are unweighted in columns (1), (4) and (7) and weighted in order to match banks with similar pre-levy trends in the remaining columns; levy is a dummy variable at the country-year level taking the value one when there is a bank levy in place; Capital Ratio indicates the regulatory capital ratio in 2008 less the median regulatory capital ratio in 2008 across all banks; size is a set of dummies indicating the quintiles in the distribution of total assets in 2008; capital is a set of dummies indicating the quintiles in the distribution of the regulatory capital ratio in 2008; region is a set of dummies indicating four geographical regions; country is a set of dummies indicating the country; regulatory is a set of variables capturing other government interventions in the banking industry than the bank levies. All regressions include the following set of controls: log of total assets, log of assets squared, ratio of pre-tax profits to assets, inflation, gdp growth and corporate tax rate. All outcomes are winsorized at the $5 / 95$ level. Standard errors are clustered at the country-year level and at the bank level; ${ }^{* * *},{ }^{* *}$ and ${ }^{*}$ indicate statistical significance at the $1 \%, 5 \%$ and $10 \%$ level respectively. 
Table 8: Stocks of assets and retail lending

\begin{tabular}{|c|c|c|c|c|c|c|}
\hline & (1) & $(2)$ & (3) & (4) & $\overline{(5)}$ & (6) \\
\hline & \multicolumn{3}{|c|}{ Assets (in logs) } & \multicolumn{3}{|c|}{ Retail lending (in logs) } \\
\hline & no weight & weight & weight & no weight & weight & weight \\
\hline \multirow[t]{2}{*}{ Levy } & -0.0299 & 0.0116 & 0.0108 & -0.0230 & 0.0094 & $0.0826 * *$ \\
\hline & $(0.0212)$ & $(0.0222)$ & $(0.0193)$ & $(0.0276)$ & $(0.0274)$ & $(0.0356)$ \\
\hline Observations & 12,680 & 12,431 & 10,936 & 12,615 & 12,366 & 10,886 \\
\hline R-squared & 0.9928 & 0.9937 & 0.9949 & 0.9865 & 0.9882 & 0.9898 \\
\hline bank FE & YES & YES & YES & YES & YES & YES \\
\hline time FE & YES & YES & YES & YES & YES & YES \\
\hline time $\mathrm{FE} \times$ size & NO & NO & YES & NO & NO & YES \\
\hline time FE $\times$ capital & NO & NO & YES & NO & NO & YES \\
\hline time $\mathrm{FE} \times$ region & NO & NO & YES & NO & NO & YES \\
\hline country $\times$ time & NO & NO & YES & NO & NO & YES \\
\hline regulatory & NO & NO & YES & NO & NO & YES \\
\hline
\end{tabular}

Note: The dependent variable is the log of total assets in columns (1)-(3) and the log of retail lending in columns (4)-(6); the regressions are unweighted in

columns (1) and (4) and weighted in order to match banks with similar pre-levy trends in columns (2)-(3) and (5)-(6); levy is a dummy variable at the country-year level taking the value one when there is a bank levy in place; size is a set of dummies indicating the quintiles in the distribution of total assets in 2008; capital is a set of dummies indicating the quintiles in the distribution of the regulatory capital ratio in 2008; region is a set of dummies indicating four geographical regions; country is a set of dummies indicating the country; regulatory is a set of variables capturing other government interventions in the banking industry than the bank levies. All regressions include the following set of controls: log of total assets, log of assets squared, ratio of pre-tax profits to assets, inflation, gdp growth and corporate tax rate. Standard errors are clustered at the country-year level and at the bank level;

$* * *, * *$ and ${ }^{*}$ indicate statistical significance at the $1 \%, 5 \%$ and $10 \%$ level respectively. 
Figure 1: Event-study of equity ratio

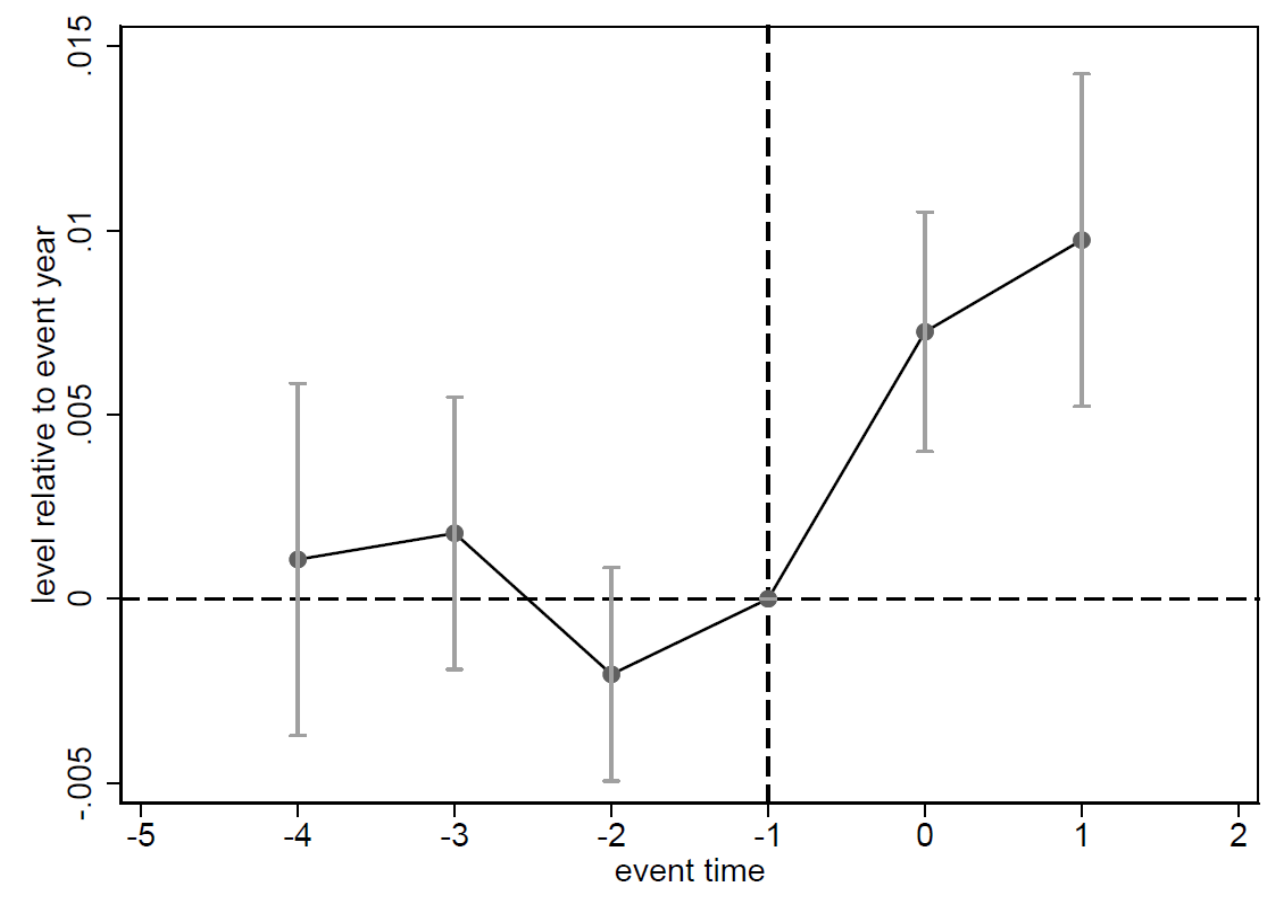

Figure 2: Event-study of average risk weight

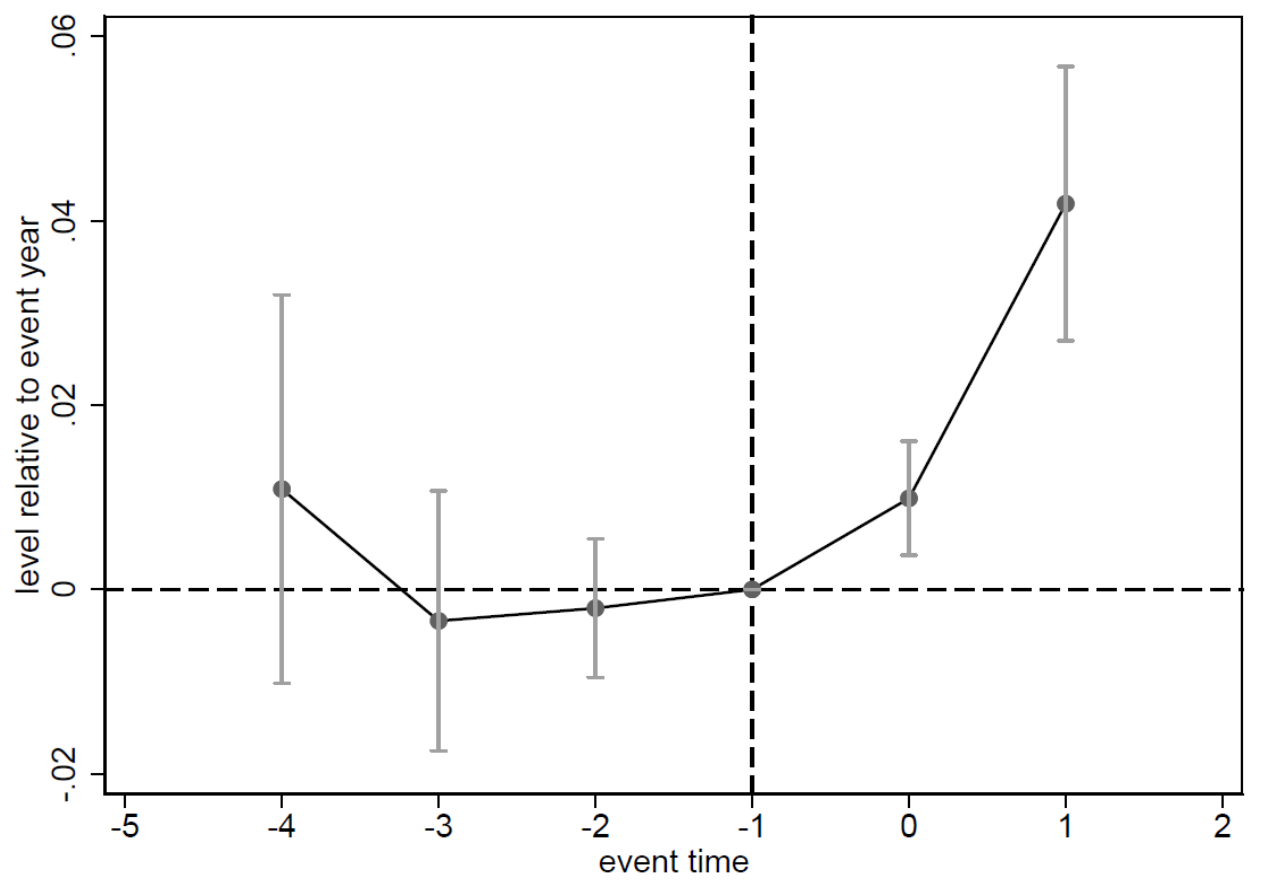

Note: Figures 1 and 2 illustrate the results from the event-study analogues of Column (2) and Column (4) in Table 3 where levy is replaced with a set of dummies indicating year relative to the introduction of a bank levy. The dependent variables are equity / total assets (Figure 1) and risk-weigted assets / assets (Figure 2). The dots indicate point estimates and the bars indicate $95 \%$ confidence bounds based on standard errors clustered at the country-year level and at the bank level. 
Figure 3: Event-study of regulatory capital ratio

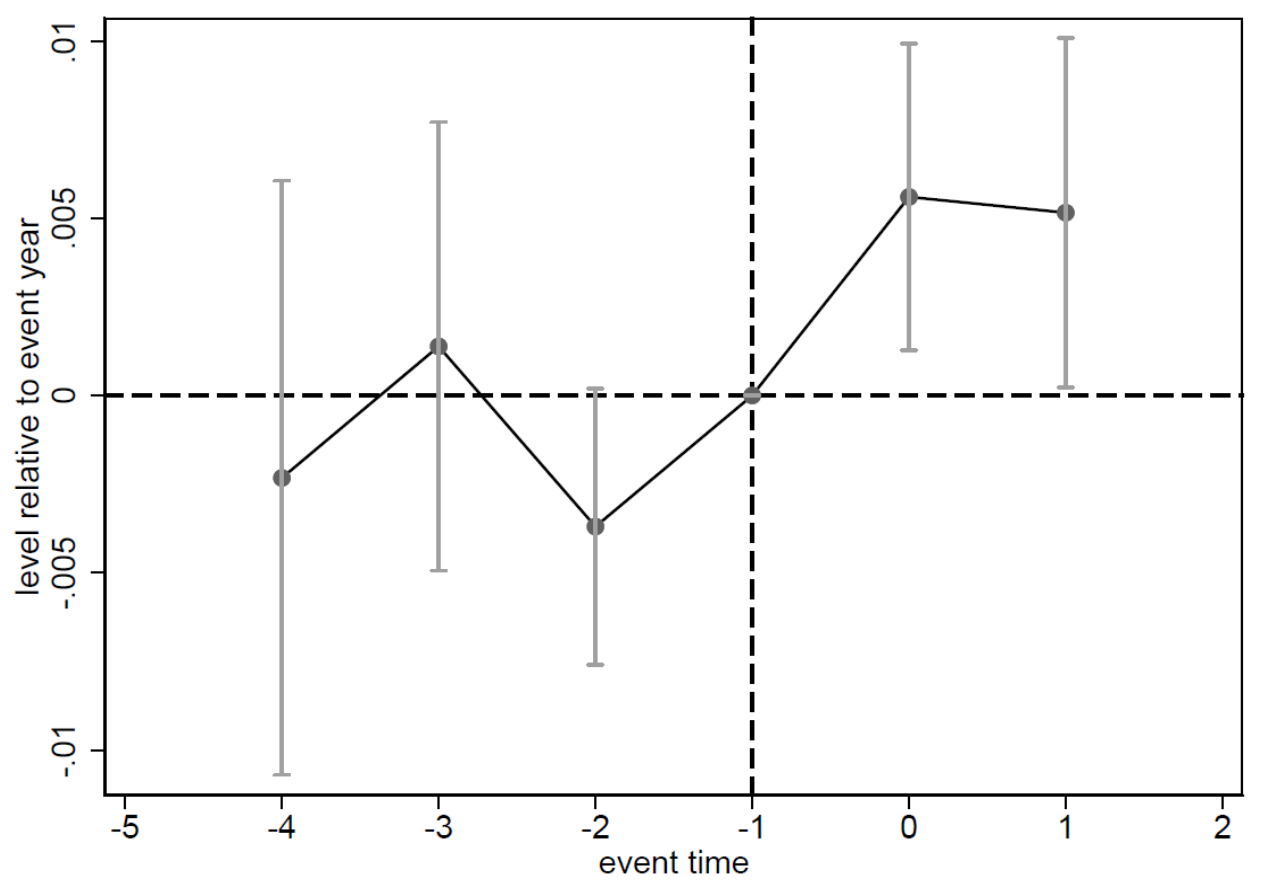

Note: Figure 3 illustrates the results from the event-study analogue of Column (6) in Table 3 where levy is replaced with a set of dummies indicating year relative to the introduction of a bank levy. The dependent variable is regulatory capital / risk-weighted assets. The dots indicate point estimates and the bars indicate $95 \%$ confidence bounds based on standard errors clustered at the country-year level and at the bank level. 
Figure 4: Event-study of equity ratio - non-financial firms

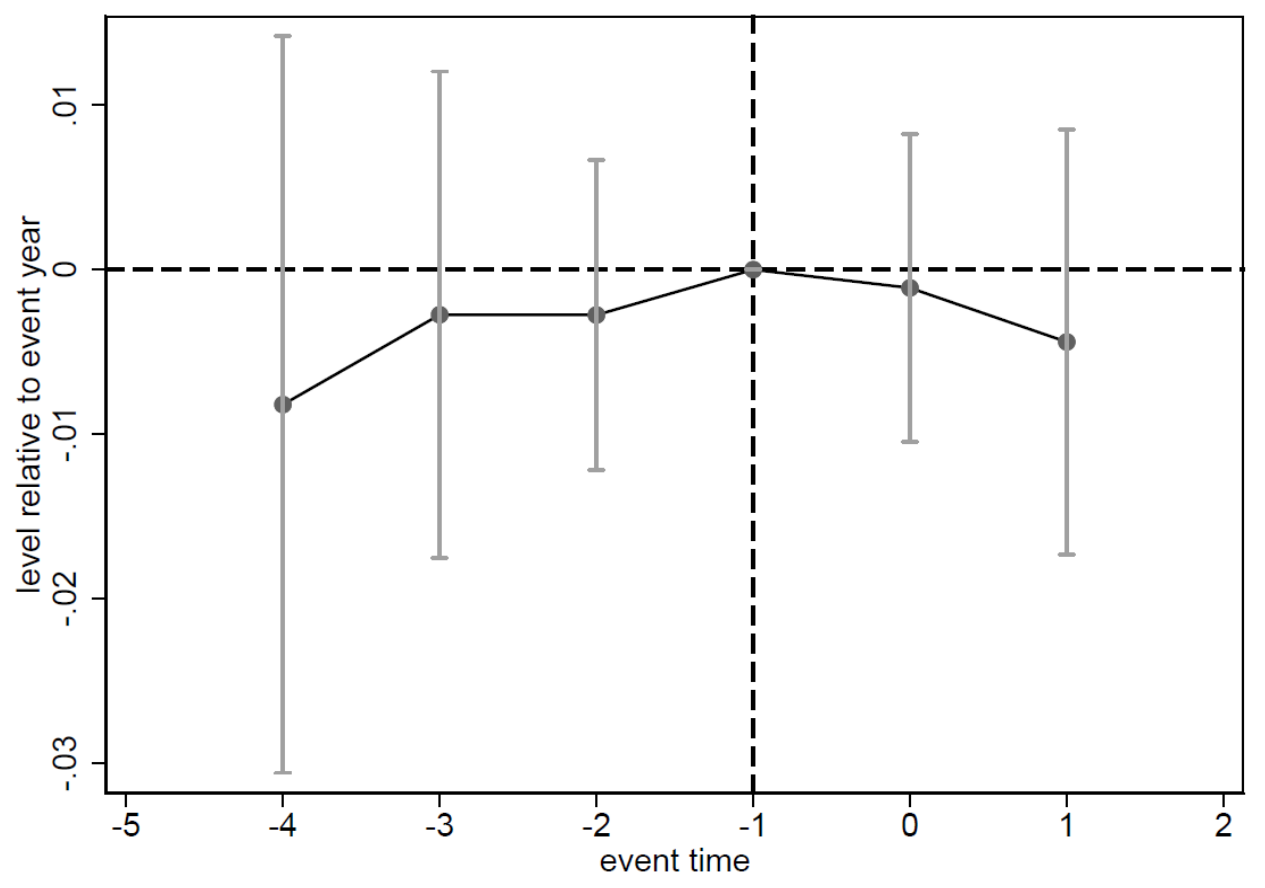

Figure 5: Event-study of equity ratio - only countries with levy

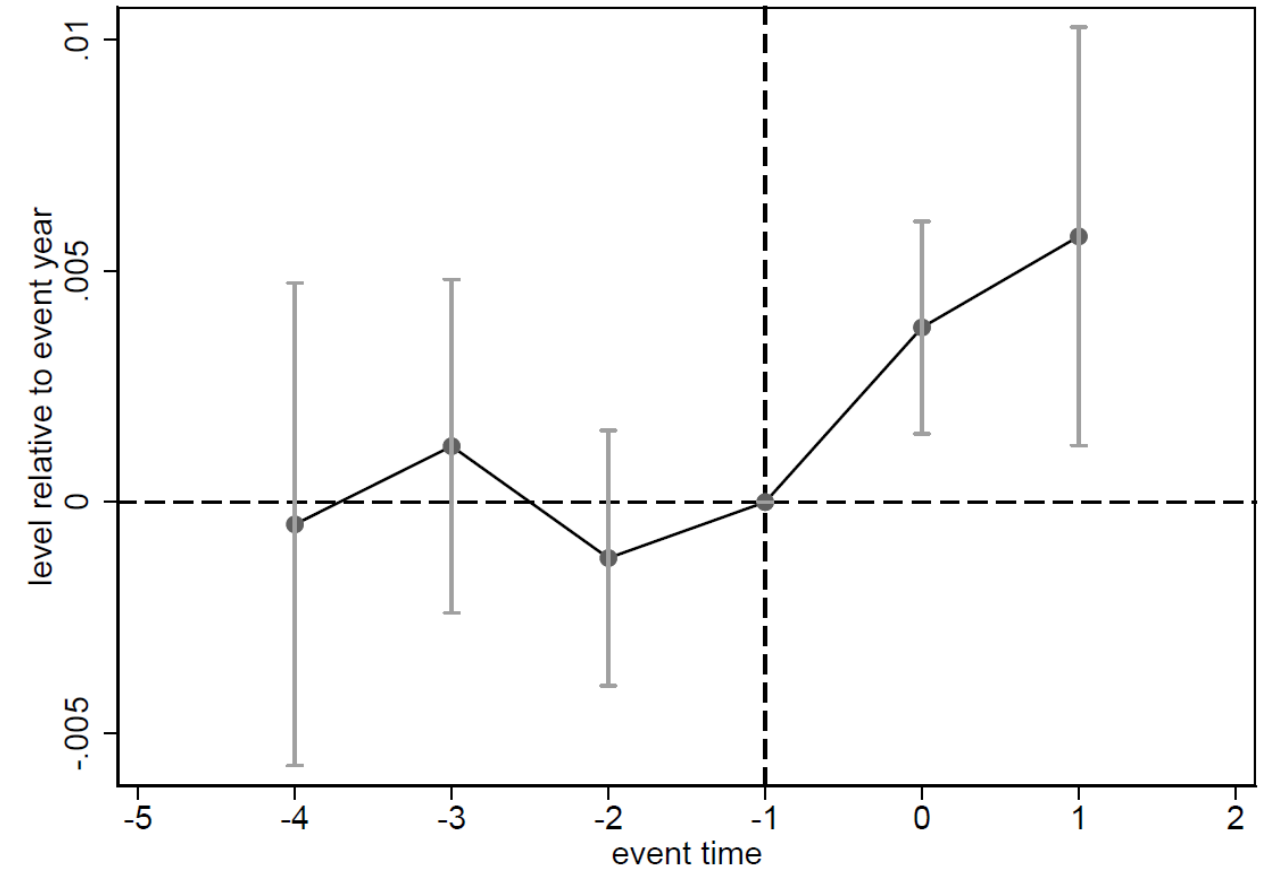

Note: Figures 4 and 5 illustrate the results from the event-study analogue of Column (2) in Table 3 where levy is replaced with a set of dummies indicating year relative to the introduction of a bank levy. In Figure 4, the sample is large non-financial firms. In Figure 5 , the sample is banks in countries introducing a levy of some type. The dependent variable is regulatory equity / total assets. The dots indicate point estimates and the bars indicate $95 \%$ confidence bounds based on standard errors clustered at the country-year level and at the bank level. 
Figure 6: Event-study of the volatility in daily stock market returns

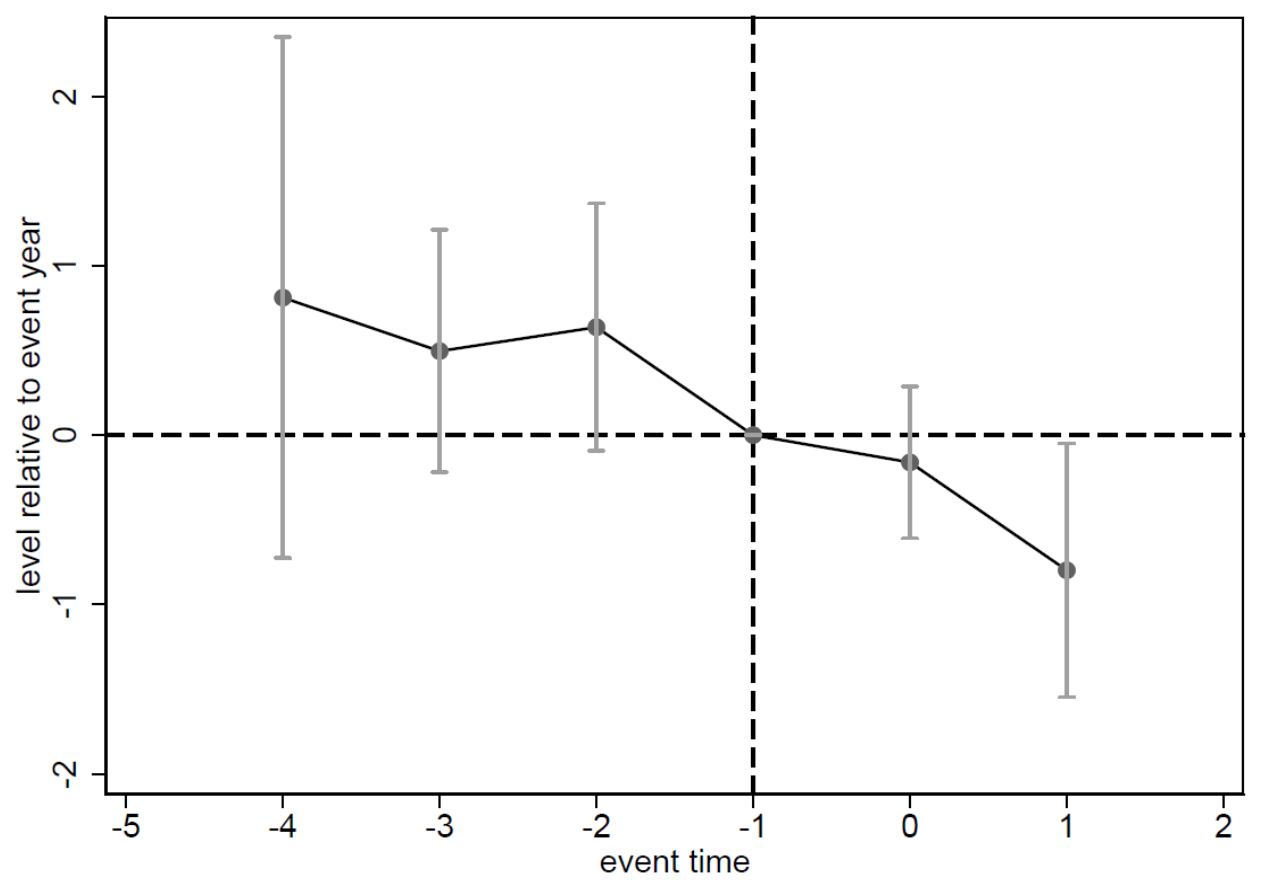

Figure 7: Event-study of absolute distance to reference book return to equity

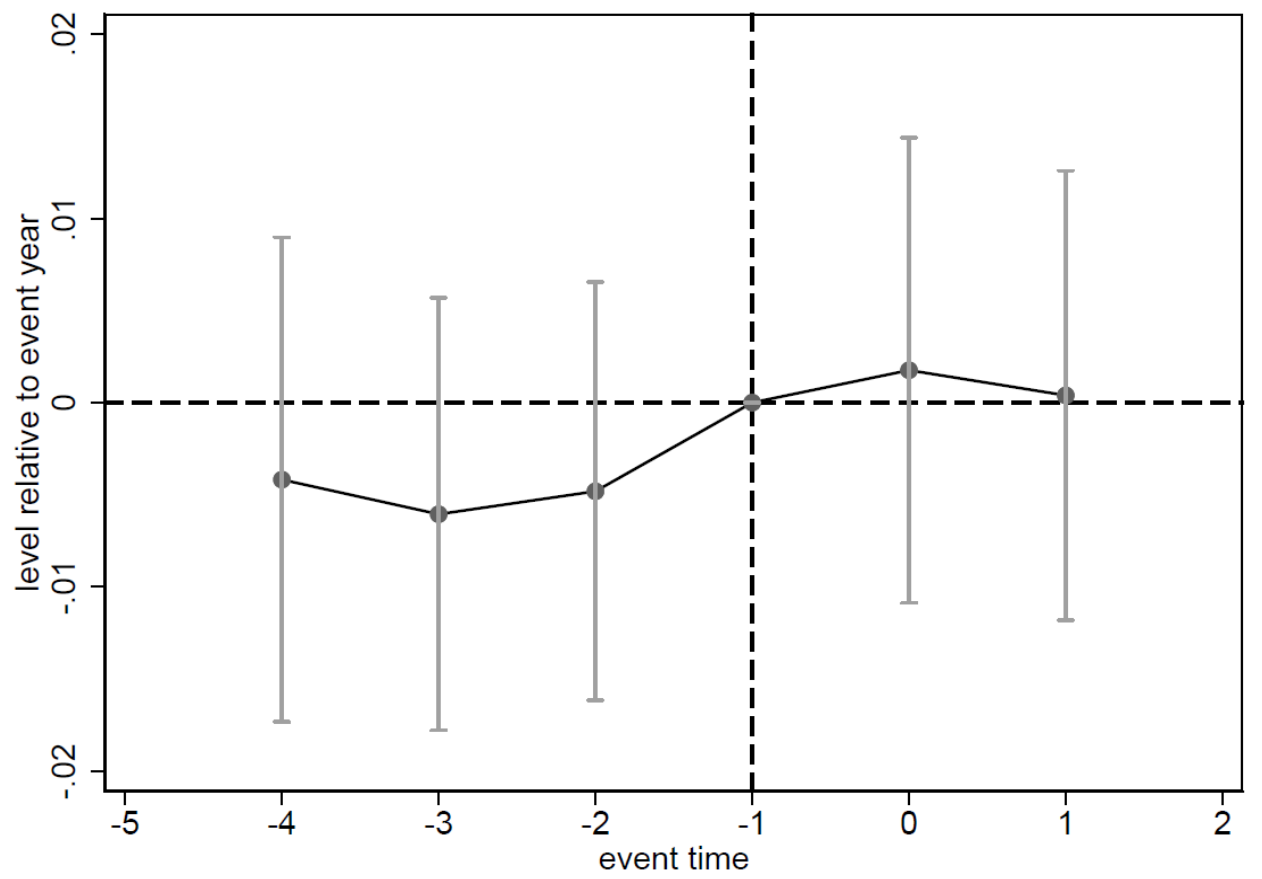

Note: Figures 6 and 7 illustrate the results from the event-study analogues of Column (3) and Column (6) in Table 6, Panel A where levy is replaced with a set of dummies indicating year relative to the introduction of a bank levy. The dependent variables are the standard deviation of daily stock market returns (Figure 6) and the absolute distance between the return to equity of the bank itself and the return to equity in a reference group. The dots indicate point estimates and the bars indicate $95 \%$ confidence bounds based on standard errors clustered at the country-year level and at the bank level. 
Figure 8: Event study of absolute distance to reference trading return

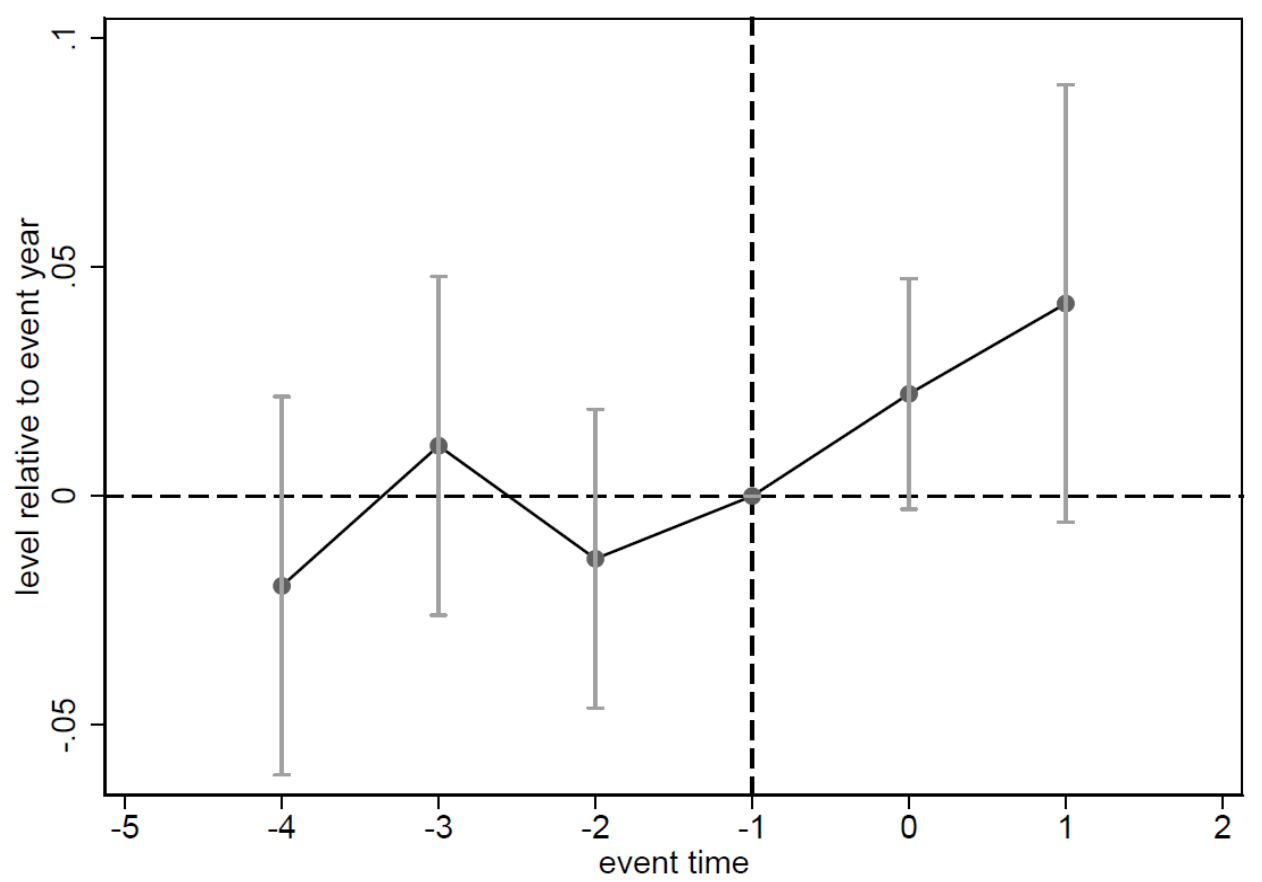

Figure 9: Event study of flow of impaired loans

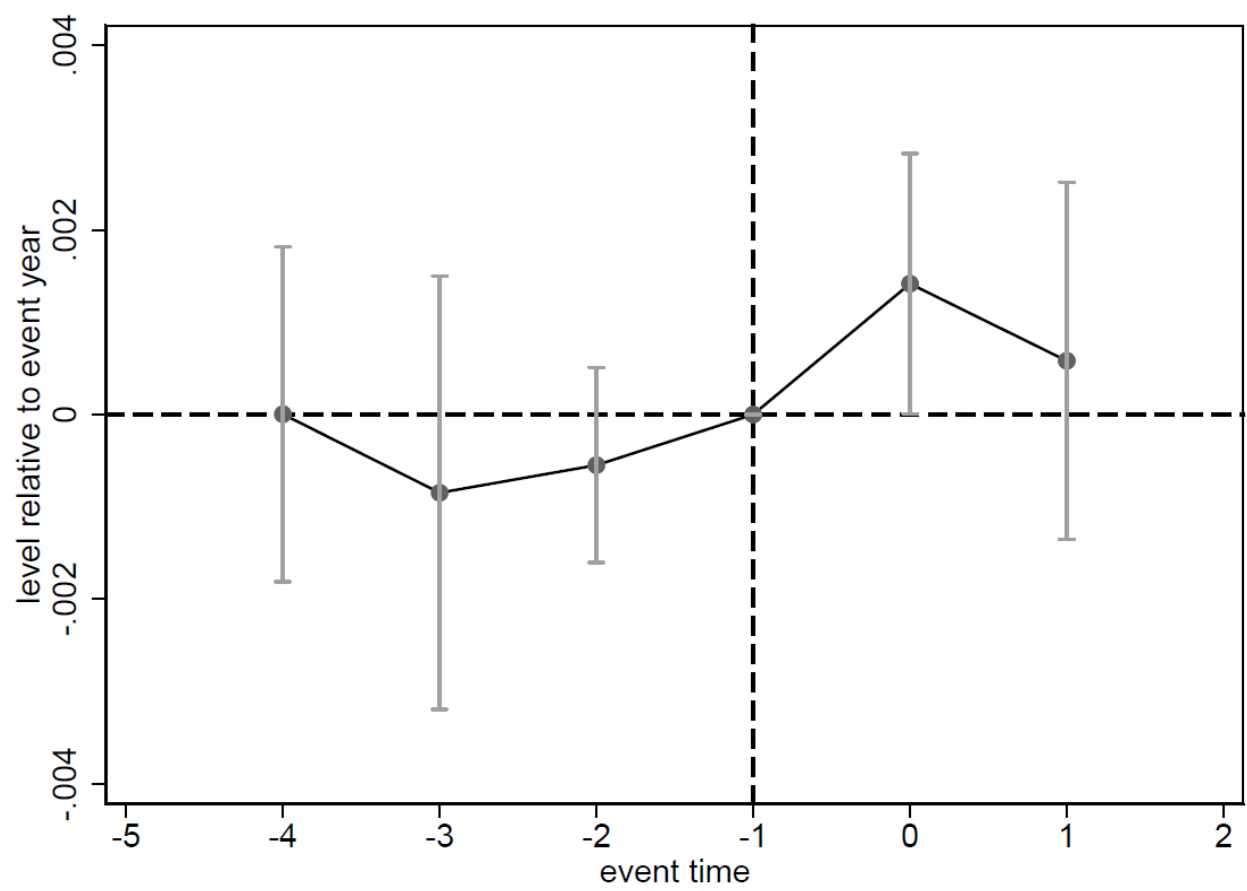

Note: Figures 8 and 9 illustrate the results from the event-study analogue of Column (3) and (6) in Table 6, Panel B where levy is replaced with a set of dummies indicating year relative to the introduction of a bank levy The dependent variables are the absolute difference between the return to secutirites and derivatives of the bank itself and the median return to secutirites and derivatives within a reference group (Figure 8 ) and the change in impaired loans scaled by gross loans (Figure 9). The dots indicate point estimates and the bars indicate $95 \%$ confidence bounds based on standard errors clustered at the country-year level and at the bank level. 